\title{
Strength of Heat-Resistant Laminated Plastics up to $300^{\circ} \mathrm{C}^{*}$
}

\author{
By Benjamin M. Axilrod and Martha A. Sherman
}

\begin{abstract}
The flexural properties of samples of glass-fabric laminates were determined for several conditions of heating and testing. The laminates tested were bonded with various resins, including unsaturated-polyester, acrylic, silicone, phenolic, and melamine types. Flexural tests were made under the following conditions: (1) at $25^{\circ} \mathrm{C}$ and 50-percent relative humidity after 200 hours of heating at a temperature $T$; (2) at a temperature $T$ after 0.5 hour at the temperature $T$; (3) at a temperature $T$ after 200 hours at the temperature $T$; and (4) at $25^{\circ} \mathrm{C}$ and 50-percent relative humidity without heating prior to testing. The temperature $T$ was $150^{\circ}, 200^{\circ}$, and $250^{\circ} \mathrm{C}$ for condition $1 ; 150^{\circ}, 200^{\circ}, 250^{\circ}, 300^{\circ}$, and $375^{\circ} \mathrm{C}$ for condition 2 ; and $150^{\circ}, 200^{\circ}, 250^{\circ}$, and $325^{\circ} \mathrm{C}$ for condition 3 .

The one sample of silicone resin laminate tested was superior to the other laminates in retention of flexural properties at temperatures of $250^{\circ} \mathrm{C}$ or higher. The single phenolic laminate tested showed good retention of flexural properties when tested at elevated temperatures after 0.5 hour of heating. After prolonged heating the behavior of the phenolic sample was much less satisfactory, the strength being almost negligible at $250^{\circ} \mathrm{C}$. The sample of melamine laminate was superior to the phenolic in retention of flexural strength after prolonged heating at $200^{\circ}$ and $250^{\circ} \mathrm{C}$. The polyester laminates lost at least 80 percent of their flexural strength when tested at $250^{\circ} \mathrm{C}$. For each laminate and each test condition loss in modulus of elasticity correlated with loss in flexural strength, but the former loss was less than the latter. The results of one test in which duplicate sets of specimens were heated in still air and in rapidly moving air indicate that the loss of flexural properties during prolonged heating may depend on the method of exposing the specimens.
\end{abstract}

\section{Introduction}

The mechanical properties of glass-fabric laminates at elevated temperatures are of interest to aircraft designers, as these materials have properties that can be used to advantage in certain applications, such as radomes. Considerable work had been done prior to 1947 on the mechanical properties of various laminates at temperatures in the range of $70^{\circ}$ to $100^{\circ} \mathrm{C}$ [1 to 7], ${ }^{1}$ and a few tests were reported at temperatures of $200^{\circ} \mathrm{C}$ [8]. With the development of higher speed aircraft and guided missiles, there was a demand for infor-

* This investigation was conducted under the sponsorship and with the financial assistance of the National Advisory Committee for Aeronautics and the Air Matériel Command.

1 Figures in brackets indicate the literature references at the end of this paper. mation on the mechanical properties of laminated plastics at temperatures much higher than $100^{\circ} \mathrm{C}$.

The present investigation was undertaken to determine the flexural properties of promising laminates at temperatures up to $300^{\circ} \mathrm{C}$. Commercial resin manufacturers and laminators were informed of the project and invited to submit samples of laminates that could be expected to be heat-resistant. Glass-fabric laminates bonded with various resins including silicone, phenolic, melamine, acrylic, and unsaturated-polyester types were received and tested. This report summarizes the results of the flexural tests, made at room temperature after prolonged heating and also at elevated temperatures after both brief and prolonged heating. 
As testing at temperatures of $300^{\circ} \mathrm{C}$ presents problems not encountered in testing at room temperature or at $70^{\circ}$ to $100^{\circ} \mathrm{C}$, a considerable part of the project was devoted to the development of suitable equipment and procedures. These are described in detail in this report.

\section{Materials}

The materials, submitted in sheets approximately $1 / 8$ in. in thickness, are identified in this report as follows:

\begin{tabular}{|c|c|}
\hline Laminate sample & Resin designation \\
\hline $\begin{array}{l}\text { Unsaturated polyester: } \\
\quad A \\
\quad C_{C} \\
\text { Arcrylic addition: } \\
\quad C\end{array}$ & $\begin{array}{l}\text { Laminac PDL-7-261. } \\
\text { Plaskon 911-11. } \\
\text { Thalid X-528-10A. C. } \\
\text { Paraplex P-43. } \\
\text { BCM monomer and poly- } \\
\quad \text { methyl methacry- } \\
\text { late. } \\
\text { DC } 804 \text {. } \\
\text { Redux. } \\
\text { Melmac } 405 \text {. }\end{array}$ \\
\hline
\end{tabular}

All the laminates except the sample $J$ were made with Fiberglas 181A fabric; Fiberglas ECC-128 was used in sample $J$. The materials are described in detail, including fabrication conditions, in table 1 .

\section{Test Procedures}

\section{Flexural Specimens and Sampling}

It is known that the sheet-to-sheet variability, especially in experimental laminates, may be large. A proper sampling plan for the tests at various conditions could give information both as to the average behavior of the sheets of a given sample, and also the variations that might be expected both at standard test conditions and elevated temperatures. Since both the number of sheets and the sizes differed from sample to sample, it was not practical to study sheet-to-sheet variability.

The following sampling plan was adopted: Approximately 80 percent of each sheet of each sample was cut into specimens, which were numbered. The numbered specimens were arranged in a random order and separated into groups of seven each. The plan was to test five specimens from each group with two specimens for use in case of experimental difficulties. The statistical analysis of the results can be greatly facilitated by having the same number of test specimens for each condition.

The flexural specimens were $4 \mathrm{in}$. long and were machined to a width of 1.00 in., either by dry grinding with a surface grinder or milling with a carbide-tipped cutter.

\section{Flexural Test Equipment ${ }^{2}$}

The flexural jig and the heated test enclosure are shown in figures 1 and 2 in place in the testing machine. The flexural jig and test enclosure are both suspended from the upper cross-head of the testing machine. The flexural jig, partly disassembled, is shown in figure 3. The base of the flexural jig has slots located so that the support blocks may be bolted in place to give a span of 2 ,

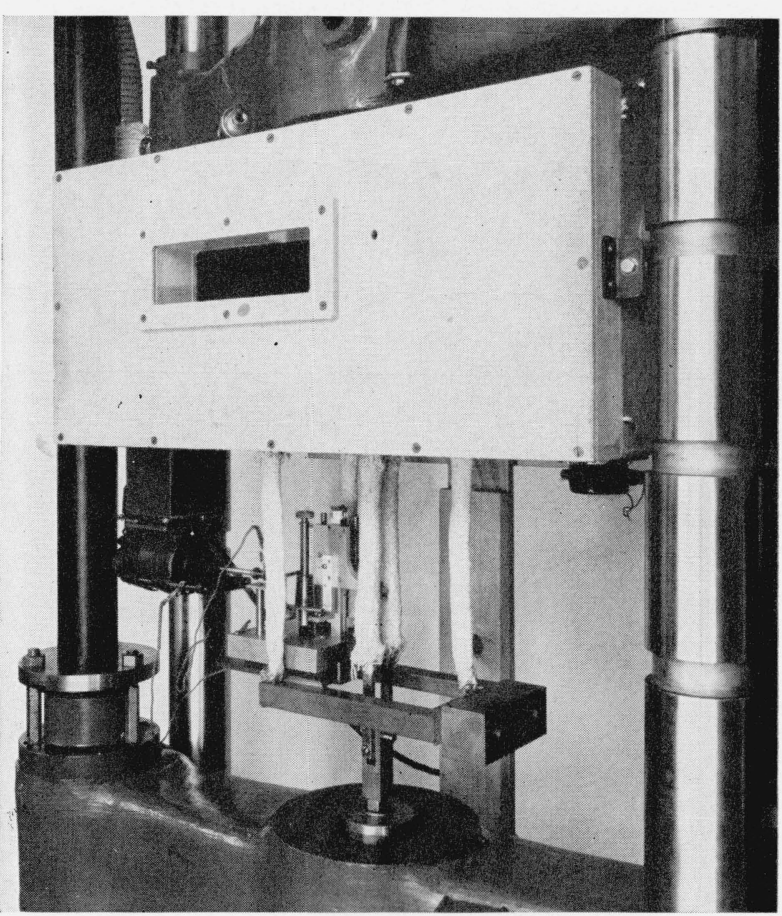

Figure 1. Front view of flexural test enclosure in place in the testing machine.

The recording deflectometer and selsyn motor are at the left below the enclosure.

${ }^{2}$ Drawings of the flexural test equipment are available from the Organic Plastics Section, National Bureau of Standards, Washington 25, D. C. 
TABLE 1. Description of materials

\begin{tabular}{|c|c|c|c|c|}
\hline & Sample A & Sample E & Sample F & Sample G \\
\hline Laminator of sample... & American Cyanamid $\mathrm{Co}$ & Plaskon Division.-- & $\begin{array}{l}\text { Monsanto Chemical } \\
\text { Co. }\end{array}$ & Rohm \& Haas Co. \\
\hline Resin used: & & & & \\
\hline $\begin{array}{l}\text { Trade name and number } \\
\text { Chemical type }\end{array}$ & $\begin{array}{l}\text { Laminac PDL-7-261, B-11_.-- } \\
\text { Polyester }\end{array}$ & $\begin{array}{l}\text { Plaskon 911-11 } \\
\text { Polyester }\end{array}$ & $\begin{array}{l}\text { Thalid } \mathrm{X}-528-10 \mathrm{AC} \\
\text { Unsaturated polyes- } \\
\text { ter; vinyl type } \\
\text { monomers. }\end{array}$ & $\begin{array}{l}\text { Paraplex } \mathrm{P}-43 \text {. } \\
\text { Unsaturated polyes- } \\
\text { ter-styrene. }\end{array}$ \\
\hline $\begin{array}{l}\text { Catalyst used with resin: } \\
\text { Name or type } \\
\text { Amount, \% }\end{array}$ & Luperco $\mathrm{ATC}^{\mathrm{a}}$ & Luperco ATCs & 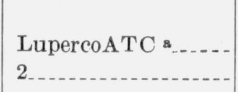 & $\begin{array}{l}\text { Benzoyl peroxide. } \\
1 .\end{array}$ \\
\hline $\begin{array}{l}\text { Liquid added to resin to prepare it for application to fabric: } \\
\text { Name. } \\
\text { Amount, parts per } 100 \text { parts of resin }\end{array}$ & Styrene 4 - 40 & None & None & $\begin{array}{l}\text { Styrene. } \\
15 .\end{array}$ \\
\hline $\begin{array}{l}\text { Resin content (by weight) of finished panel: } \\
\text { Manufacturer's data, \% } \\
\text { National Bureau of Standards data, \% }\end{array}$ & $33 \pm 2$ & $31 \ldots$ & 45 & $\begin{array}{l}40 \text { to } 45 \text {. } \\
42 .\end{array}$ \\
\hline Fabric used: & & & & \\
\hline Identity & Fiberglas $181-\mathrm{A}-14 \ldots$ & $\begin{array}{l}\text { Fiberglas } 181-\mathrm{A}-14 \ldots \\
15\end{array}$ & $\begin{array}{l}\text { O. C. C. } 181-\mathrm{A}-14 \ldots \\
15\end{array}$ & $\begin{array}{l}\text { Fiberglas } 181-38, \\
\text { Finish } 114 .\end{array}$ \\
\hline Ply arrangement & Parallel & Parallel & Cross & Cross. \\
\hline Treatment prior to application of resin (drying, etc.) -..- & None_-_............... & $\begin{array}{l}\text { In forced-draft oven } \\
\text { for } 2 \mathrm{hr} \text { at } 204^{\circ} \mathrm{C} \text {. }\end{array}$ & None & None. \\
\hline Method of applying resin.. & Dipping --. & $\begin{array}{l}\text { By hand with broad- } \\
\text { blade spatula. }\end{array}$ & Brush & Brush. \\
\hline Drying of impregnated fabric & & & & \\
\hline $\begin{array}{l}\text { Molding conditions: } \\
\text { Equipment: }\end{array}$ & & & & \\
\hline $\begin{array}{l}\text { Heat-............ } \\
\text { Pressure }\end{array}$ & Steam & Steam & Steam & Steam. \\
\hline Precure & None-...................... & None................... & None............. & Hentanc press. \\
\hline Temperature, ${ }^{\circ} \mathrm{C} \ldots \ldots . . . . .$. & -... & & & 104. \\
\hline $\begin{array}{l}\text { Pressure, lb/in. } 2 \\
\text { Time, min }\end{array}$ & - non & 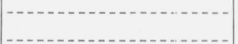 & - & 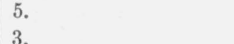 \\
\hline Cure: & $\int 105,15 \mathrm{~min}$. & & & 3. \\
\hline Temperature, ${ }^{\circ} \mathrm{C}_{-}$ & $\left\{\begin{array}{l}105,15 \mathrm{~min} . .- \\
125,10 \mathrm{~min} . .-\end{array}\right.$ & $100 \ldots$ & 100 to 110 & 145. \\
\hline Pressure, $\mathrm{lb} / \mathrm{in} .^{2}$ & $10 \ldots$ & $25 \ldots \ldots$ & $15 \ldots \ldots$ & 50. \\
\hline Time of heating under pressure, $\min . . .$. & $25 \ldots$ & $30 \ldots \ldots$ & $15 \ldots \ldots$ & 5. \\
\hline Time of cooling under pressure, min & None......... & None & 5 & None. \\
\hline Aftercure & - do & ..... do & None.............. & Do. \\
\hline Sample: & & & & \\
\hline Area, in & 21 by $22 \ldots$ & 12 by $12 \ldots$ & 12 by $12 \ldots$ & 10 by 10. \\
\hline Thickness, in & 0.11 to $0.13 \quad 0.11$ to $0.13 \ldots$ & 0.13 to $0.14 \ldots$ & 0.09 to $0.12 \ldots$ & 0.13 to 0.15 \\
\hline Number of sheets. & $1 \quad 1$ & $10 \ldots \ldots$ & 4 & 14. \\
\hline
\end{tabular}

a Luperco A TC consists of $50 \%$ benzoyl peroxide and $50 \%$ tricresyl phosphate. 
TABLE 1. Description of materials-Continued

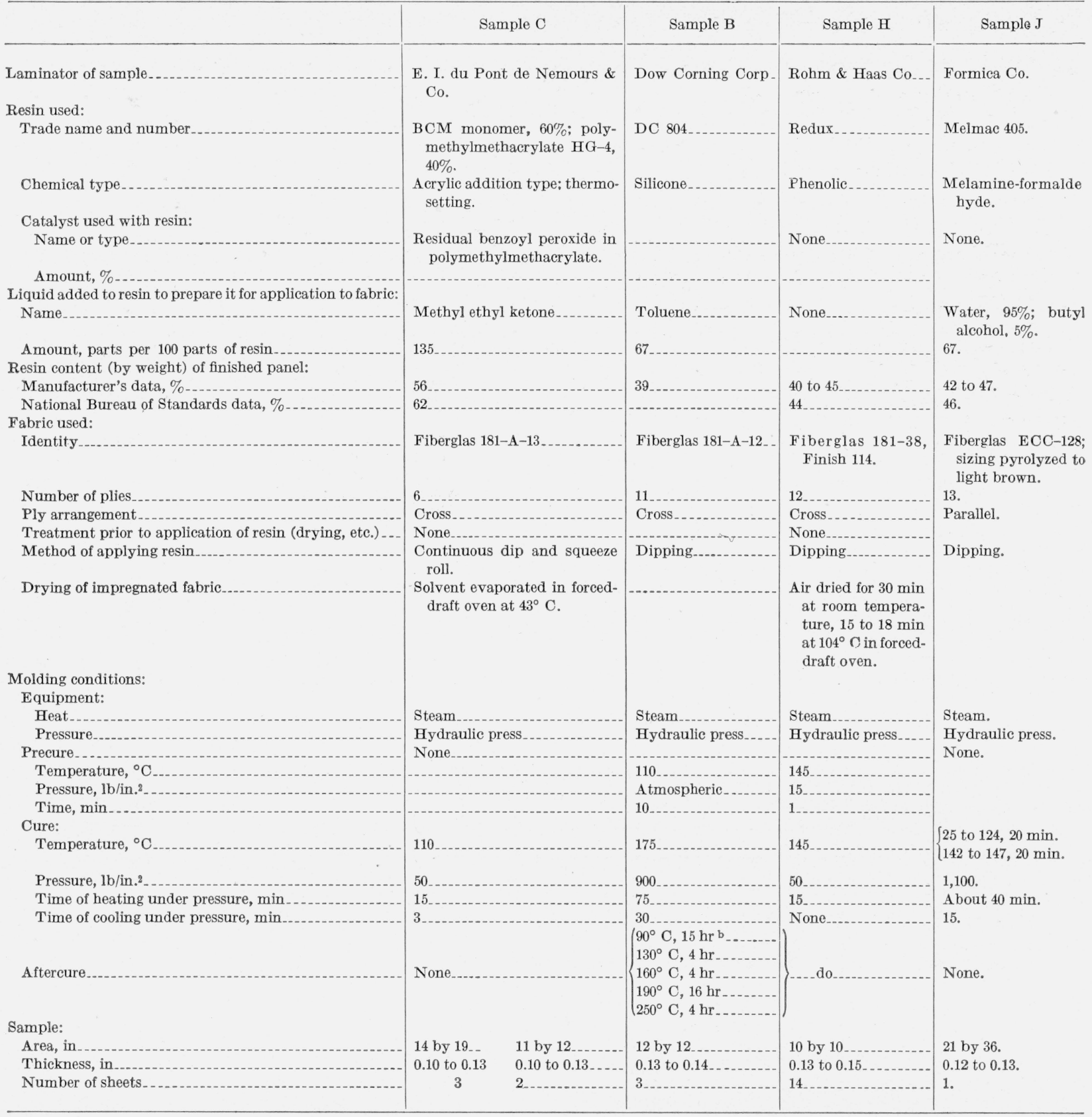

b Mechanical convection oven. 


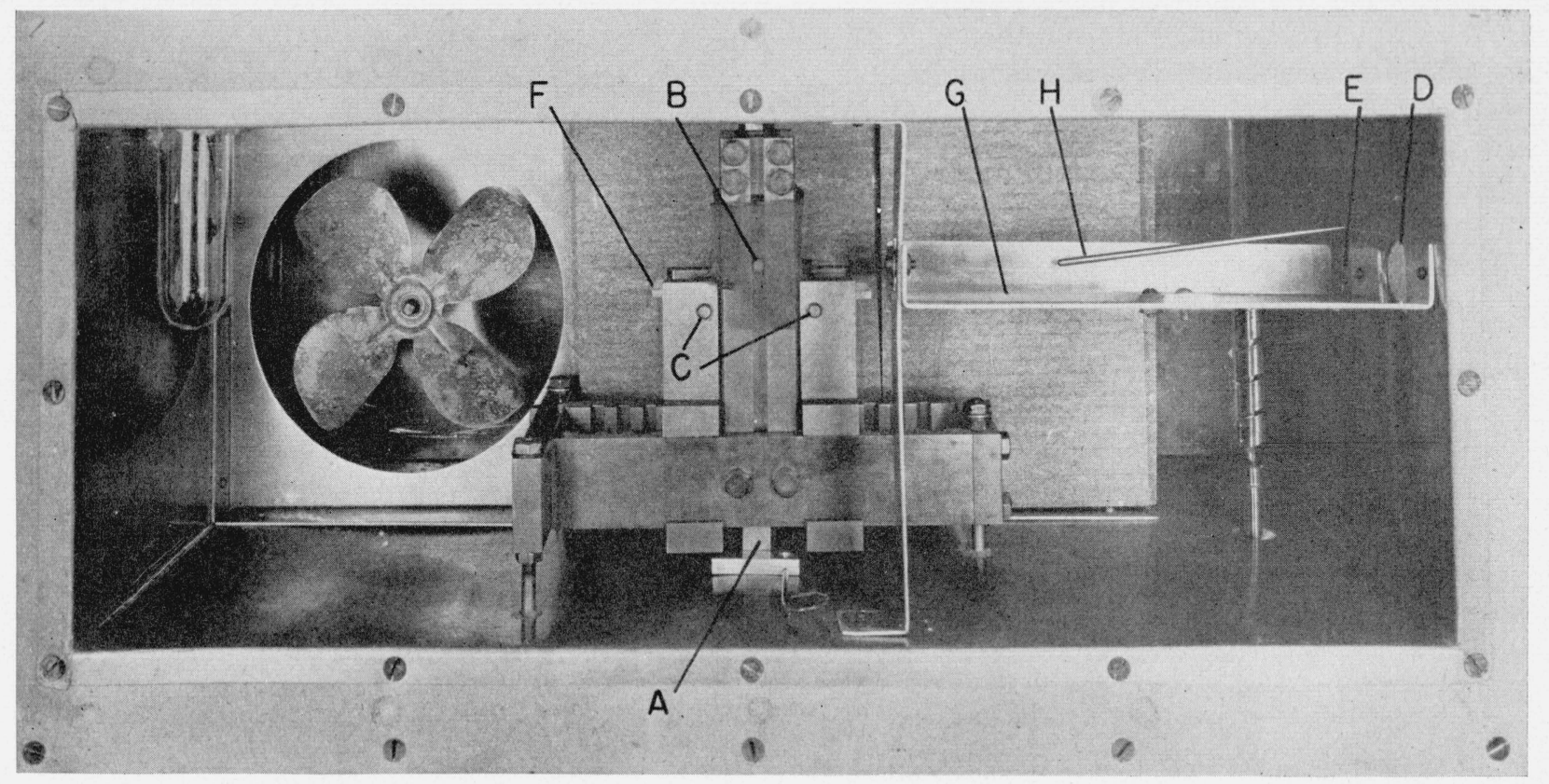

FIGURE 2. Interior view of test enclosure.

$A$, Loading stirrup; $B$, loading edge in loading stirrup; $C$, contact edges in support block; $D$, loading port; $E$, hole for push rod; $F$, specimen in jig; $G$, specimen in tray; $H$, stem of dial-type thermometer.

3,4 , or 5 in. The loading stirrup, attached to the lower cross-head of the testing machine (fig. 1), is centered by having the ends of the drill rod used for the loading edge extend into slots

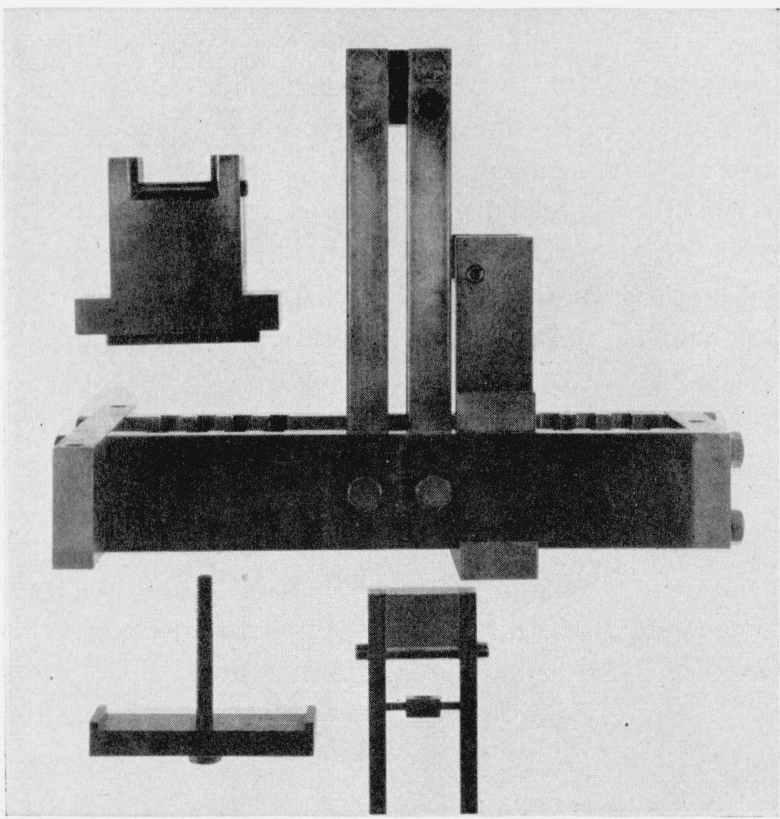

Figure 3. Flexural jig partly disassembled.

The left support block and clamp and the loading stirrup have been removed and rotated through $90^{\circ}$. in the flexural jig suspension (see figs. 2 and 3 ). The flexural jig is made of steel, nickel-plated to avoid corrosion.

The deflection of the specimen is measured by a Southwark-Peters deflectometer, model PD-1, coupled to a recorder on the testing machine to produce load-deflection graphs. The deflectometer, located below the test enclosure (fig. 1), is supported by a platform attached to the flexural jig base. A glass push rod touching the lower side of the specimen operates the deflectometer; this rod is centered by a guide in the loading stirrup (fig. 3).

The test enclosure has an asbestos board exterior, a sheet aluminum interior, and Fiberglas insulation about $1.75 \mathrm{in}$. thick. The interior is divided into two compartments by an aluminum partition; the front compartment is the test chamber and the rear compartment contains a bank of five 250-w strip heaters. A fan operating continuously draws air past the heaters and blows it into the test chamber. After a number of tests had been made, it was found desirable to place two layers of $\frac{1}{4}-$ in.-thick asbestos board in front of the partition (fig. 2) to improve the temperature distribution within the test chamber.

The specimens are inserted with a spatula-like 
holder through a loading port and then placed side by side on an aluminum specimen tray, visible at the right of figure 2. This tray holds five 1-in.-wide specimens. The specimens are manipulated into place in the flexural jig by push rods inserted into holes in the front and right side of the enclosure. In figure 2 one specimen is shown in place in the flexural jig and one in the specimen tray. After a test the specimen is removed from the flexural jig with a pair of tongs inserted through a port in the left side of the enclosure. The operation of the equipment is aided by a double-paned Pyrex glass window and a projection bulb located inside the enclosure. To avoid failure of the phenolic plastic socket or the bulb, the latter is operated at lower than rated voltage by means of a variable auto transformer, and the socket is attached to the outer wall of the enclosure.

Preliminary temperature measurements were made with thermocouples located inside and on the surface of specimens in both the specimen tray and in the flexural jig. It was found that a specimen came to temperature equilibrium within 10 to 15 min after insertion in the enclosure. Before the asbestos board was added to the partition, the temperature of a specimen in the tray was appreciably less than that of a specimen in the flexural jig, the differences amounting to $3 \mathrm{deg}$ and $7 \mathrm{deg} \mathrm{C}$ at enclosure temperatures of $150^{\circ}$ and $250^{\circ} \mathrm{C}$, respectively. The difference was reduced to $3 \mathrm{deg}$ $\mathrm{C}$ at $250^{\circ} \mathrm{C}$ by insertion of the asbestos board.

A fine mesh screen (fig. 2) was wrapped around the upper part of the flexural jig to keep particles of Fiberglas or resin out of the guides for the loading stirrup.

In testing at elevated temperatures the gaseous products given off by some of the specimens were a source of trouble, as the testing machine was located in a controlled atmosphere room in which the air was recirculated. The problem became more serious as the test temperature was increased. An exhaust pipe equipped with a blower was finally attached to the box; it was necessary to control the amount of air drawn from the enclosure by means of a valve in the exhaust pipe, as otherwise the temperature of the enclosure could not be maintained constant.

\section{Flexural Test Procedure}

(a) Temperature Conditions

Sets of specimens of the samples were tested at $25^{\circ} \mathrm{C}$ after heating at temperatures of $150^{\circ}, 200^{\circ}$, and $250^{\circ} \mathrm{C}$ for $200 \mathrm{hr}$. Other sets of specimens were tested at an elevated temperature $T$ after $0.5 \mathrm{hr}$ or $200 \mathrm{hr}$ at the temperature $T$. The temperatures ranged up to $375^{\circ} \mathrm{C}$ in the 0.5 -hr tests and $325^{\circ} \mathrm{C}$ in the 200 -hr tests. Each sample was not tested at each set of conditions; in some instances the samples were badly weakened at moderate test conditions, and in other instances sufficient material was not available.

Two control sets of specimens of each sample were tested at $25^{\circ} \mathrm{C}$ and 50-percent relative humidity. One set was tested at the beginning of the testing program, the other set about $7 \mathrm{mo}$ later, near the end of the tests.

In heating the specimens for $200 \mathrm{hr}$, a circulating-air oven was used with each specimen in an open wide-mouthed glass bottle of 2-in. diameter and 4-in. height. In one experiment specimens were also placed on asbestos board laid on the oven shelf in order to compare the effect of heating in still air with heating in rapidly moving air. For convenience, the $200-\mathrm{hr}$ heating period was interrupted at about $96 \mathrm{hr}$, and the specimens were allowed to cool in the glass containers for about $18 \mathrm{hr}$; the heating was then continued for about $103 \mathrm{hr}$. The specimens were transferred to the heated test enclosure $1 \mathrm{hr}$ prior to testing; in making the transfer the specimens were transported to the immediate vicinity of the test enclosure in their containers to minimize cooling; transfer from the container into the test enclosure took a few seconds. During all the 200-hr heating periods the oven temperature was recorded with a Brown recording potentiometer and a thermocouple.

In the tests at elevated temperatures after the specimens were heated $0.5 \mathrm{hr}$, it was considered that the thermal shock when a cold specimen was placed on the hot metal specimen tray might weaken the specimens. Accordingly, in some tests the specimen tray was covered with a sheet of $1 / 16$-in.-thick asbestos paper. 
In tests at $25^{\circ} \mathrm{C}$ and 50-percent relative humidity, the specimens were normally conditioned for 7 days prior to test in a room whose atmosphere was controlled at the above values.

\section{(b) Flexural Test Conditions}

The flexural jig span was set for 2 in. The actual span was determined at $25^{\circ} \mathrm{C}$ with screw micrometer calipers. The contact edges of the supporting and loading pieces were all of $1 / 4$-in.diameter drill rod. The rate of loading was maintained at $0.04 \mathrm{in} . / \mathrm{min}$ in all tests.

\section{(c) Calculation of Flexural Data}

In calculations of tests at elevated temperatures the specimen dimensions obtained at $25^{\circ} \mathrm{C}$ and 50 -percent relative humidity were used; however, the span was corrected for change with temperature, assuming a thermal expansivity of $12 \times 10^{-6}$ per $\operatorname{deg} \mathrm{C}$ for the metal in the jig. The stress range chosen for calculating the flexural secant modulus of elasticity values was about one-half to two-thirds of the flexural strength at the test condition concerned.

\section{(d) Resin Content and Loss of Weight on Heating}

The resin content was determined for three sets of flexural specimens, except for the laminate made with the silicone resin which could not be completely burned off. The initial weights were determined after the specimens were conditioned for at least 7 days at $25^{\circ} \mathrm{C}$ and 50-percent relative humidity. The resins were removed from the specimens by heating in a muffle furnace.

The weight loss after $200 \mathrm{hr}$ of heating was determined by weighing some of the sets of specimens prior to heating and reweighing after the specimens were reconditioned 7 days at $25^{\circ} \mathrm{C}$ and 50-percent relative humidity.

\section{(e) Tolerances on Temperatures and Times of Heating}

The temperature in the circulating-air oven was controlled at the nominal value to within $\pm 5^{\circ} \mathrm{C}$ during the 200-hr heating period. In the heating at $325^{\circ} \mathrm{C}$ in a muffle furnace, the temperature fluctuations were $\pm 10 \mathrm{deg} \mathrm{C}$ relative to $325^{\circ} \mathrm{C}$.

In the test chamber the average temperature for each set of five specimens noted at the specimen at the start of the flexural test was within $\pm 3 \operatorname{deg} \mathrm{C}$ of the test temperature reported in tables 2 and 3 with only one exception. The latter occurred in testing sample $B$ at approximately $375^{\circ} \mathrm{C}$ after heating for $0.5 \mathrm{hr}$, the average test temperature being $368^{\circ} \mathrm{C}$. In more than 90 percent of the tests the average test temperature was within $2 \mathrm{deg} \mathrm{C}$ of the desired value. The individual test temperatures were within $-5 \mathrm{deg}$ and $+3 \operatorname{deg} \mathrm{C}$ of the nominal values except for the tests at $375^{\circ} \mathrm{C}$ for which the range was $367^{\circ}$ to $381^{\circ} \mathrm{C}$.

In the tests at a temperature $T$ after $0.5 \mathrm{hr}$ at the temperature $T$, the actual time of heating at the start of the flexural tests was 30 to $35 \mathrm{~min}$. In the 200-hr tests, the total time of heating was $200 \pm 1 \mathrm{hr}$. 
TABLE 2. Flexural strength data for specimens of glass-fabric laminates tested under various conditions of temperature and heating s

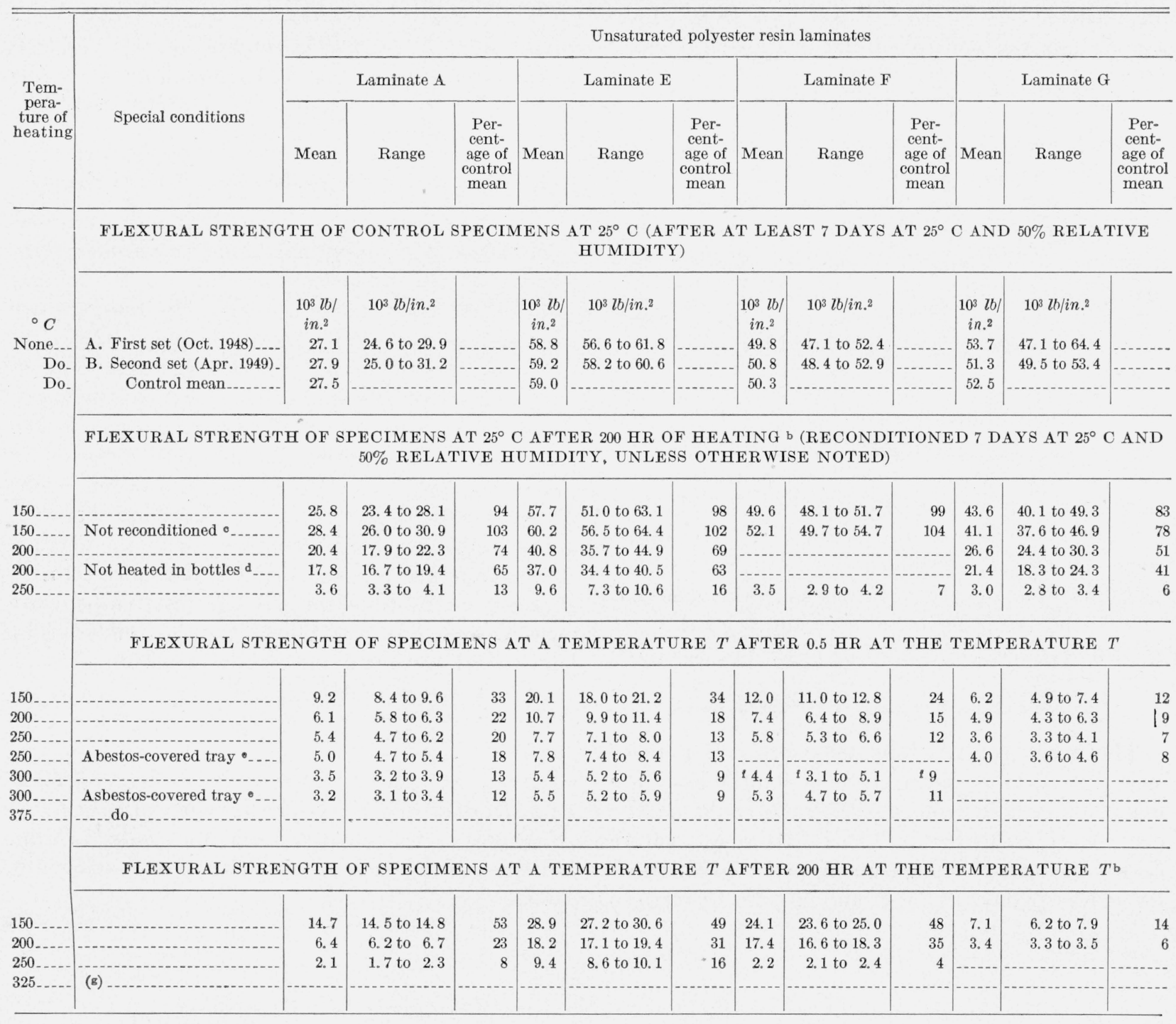

See footnotes at end of table. 
TABLE 2. Flexural strength data for specimens of glass-fabric laminates tested under various conditions of temperature and heating a-Continued

\begin{tabular}{|c|c|c|c|c|c|c|c|c|c|c|c|c|c|}
\hline \multirow[b]{2}{*}{$\begin{array}{l}\text { Tem- } \\
\text { pera- } \\
\text { ture of } \\
\text { heating }\end{array}$} & \multirow[b]{2}{*}{ Special conditions } & \multicolumn{3}{|c|}{ Acrylic laminate $\mathrm{C}$} & \multicolumn{3}{|c|}{ Silicone laminate B } & \multicolumn{3}{|c|}{ Phenolic laminate $\mathrm{H}$} & \multicolumn{3}{|c|}{ Melamine laminate $\mathrm{J}$} \\
\hline & & Mean & Range & $\begin{array}{c}\text { Per- } \\
\text { centage } \\
\text { of con- } \\
\text { trol } \\
\text { mean } h\end{array}$ & Mean & Range & $\begin{array}{c}\text { Per- } \\
\text { centage } \\
\text { of con- } \\
\text { trol } \\
\text { mean }\end{array}$ & Mean & Range & $\begin{array}{c}\text { Per- } \\
\text { centage } \\
\text { of con- } \\
\text { trol } \\
\text { mean }\end{array}$ & Mean & Range & $\begin{array}{l}\text { Per- } \\
\text { centage } \\
\text { of con- } \\
\text { trol } \\
\text { mean }\end{array}$ \\
\hline
\end{tabular}

FLEXURAL STRENGTH OF CONTROL SPECIMENS AT $25^{\circ} \mathrm{C}$ (AFTER AT EAST 7 DAYS AT $25^{\circ} \mathrm{C}$ AND $50 \%$ RELATIVE HUMIDITY)

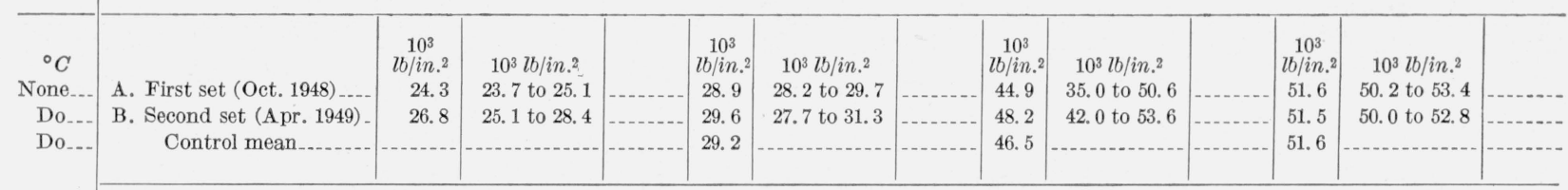

FLEXURAL STRENGTH OF SPECIMENS AT $25^{\circ} \mathrm{C}$ AFTER 200 HR OF HEATING b (RECONDITIONED 7 DAYS AT $25^{\circ} \mathrm{C}$ AND 50\% RELATIVE HUMIDITY, UNLESS OTHERWISE NOTED)

\begin{tabular}{|c|c|c|c|c|c|c|c|c|c|c|c|c|c|}
\hline $150 \ldots$ & & 28. 2 & 26.8 to 29.4 & $116(\mathrm{~A})$ & 27.7 & 26.2 to 30.3 & 95 & 40.1 & 36.4 to 42.6 & 86 & 33.8 & 31.8 to 35.0 & 66 \\
\hline $150 \ldots$ & Not reconditioned ${ }^{\circ}$ & 31.7 & 27.6 to 34.9 & $130(\mathrm{~A})$ & 28.0 & 26.6 to 29.1 & 96 & 40.3 & 36.3 to 43.3 & 87 & 31.6 & 31.3 to 32.1 & 61 \\
\hline $200 \ldots$ & & 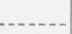 & 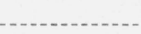 & & -..... & 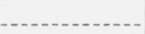 & $2=$ & 15.0 & 13.2 to 16.8 & 32 & 26.4 & 25.7 to 28.4 & 51 \\
\hline $200 \ldots$ & Not heated in bottles d... & & & & & & 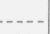 & 9.5 & 8.6 to 10.4 & 20 & 26. 0 & 25.1 to 26.8 & 50 \\
\hline $250 \ldots$ & 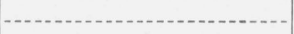 & & & & 26.4 & 25.2 to 27.7 & 90 & $<0.2$ & 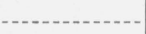 & & 17. 6 & 16.8 to 18.4 & 34 \\
\hline
\end{tabular}

FLEXURAL STRENGTH OF SPECIMENS AT A TEMPERATURE $T$ AFTER 0.5 HR AT THE TEMPERATURE $T$

\begin{tabular}{|c|c|c|c|c|c|c|c|c|c|c|c|c|c|}
\hline $150 \ldots$ & & 3.4 & 2.9 to 4.2 & $14(\mathrm{~A})$ & 12.6 & 11.3 to 13.7 & 43 & 41.9 & 39.7 to 44.4 & 90 & 37.2 & 36.4 to 38.1 & 72 \\
\hline 200 & & & & & & & & 35.3 & 28.2 to 40.6 & 76 & 26.5 & 24.8 to 27.4 & 51 \\
\hline $250 \ldots$ & 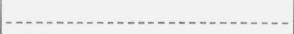 & -1 & - & $\mid-\ldots$ & 10.9 & 10.1 to 11.9 & 37 & 23.9 & 21.5 to 28.7 & 51 & 22.1 & 21.4 to 22.7 & 43 \\
\hline 250 & Asbestos-covered tray & 0.47 & 0.42 to 0.51 & 1. $8(\mathrm{~B})$ & $-\ldots$ & - & 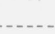 & 24.8 & 22.6 to 26.4 & 53 & 22.4 & 21.8 to 23.5 & 43 \\
\hline $300 \ldots$ & 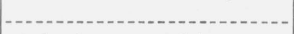 & & - & - & i 10.1 & i 9.6 to 10.9 & i 35 & 19.8 & 17.4 to 21.7 & 43 & 20.5 & 19.2 to 22.6 & 40 \\
\hline $300 \ldots$ & Asbestos-covered tray ${ }^{\circ}$ & $-\ldots$ & & -....... & 10.5 & 10.3 to 10.8 & 36 & 20.5 & 17.0 to 25.3 & 44 & 19.0 & 18.4 to 19.4 & 37 \\
\hline $375 \ldots$ & _... do 0 & & & - n & f 9.8 & f 8.8 to 10.6 & f 34 & 14. 7 & 12.3 to 16.4 & 32 & i 2.0 & i 1.4 to 2.5 & 14 \\
\hline
\end{tabular}

FLEXURAL STRENGTH OF SPECIMENS AT A TEMPERATURE $T$ AFTER 200 HR AT THE TEMPERATURE $T$ b

\begin{tabular}{|c|c|c|c|c|c|c|c|c|c|c|c|c|c|}
\hline $150 \ldots$ & & 4. 2 & 2.9 to 5.4 & $17(\mathrm{~A})$ & 14.3 & 13.4 to 15.7 & 49 & 39.1 & 36.2 to 42.6 & 84 & 30.3 & 29.4 to 32.3 & 59 \\
\hline $200 \ldots$ & & - n- & -........ & 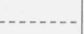 & - & - & - n- & 10.9 & 10.4 to 11.9 & 23 & 23.3 & 23.0 to 24.2 & 45 \\
\hline $250 \ldots$ & & & & & 13.4 & 12.7 to 14.0 & 46 & 0.55 & 0.51 to 0.59 & 1. 2 & 15.6 & 14.7 to 17.4 & 30 \\
\hline $325 \ldots$ & (g) & & & & 9.8 & 9.2 to 10.4 & 34 & & & & j 1.5 & j 1.5 to 1.6 & j 3 \\
\hline
\end{tabular}

- Specimens approximately $1 / 8 \mathrm{in}$. thick and $1 \mathrm{in}$. wide tested at $0.04 \mathrm{in} . / \mathrm{min}$ relative head motion with a span of $2.0 \mathrm{in.} \mathrm{Each} \mathrm{value} \mathrm{is} \mathrm{the} \mathrm{average} \mathrm{for} \mathrm{five}$ specimens, unless otherwise noted. Specimens taken at random from the sheets, unless otherwise noted.

b Unless otherwise noted, all specimens that were heated for $200 \mathrm{hr}$ were heated in open wide-mouthed bottles placed in a circulating-air oven.

- After removal from the oven, specimens kept over calcium chloride for $24 \mathrm{hr}$ prior to testing.

d Specimens laid on asbestos board on oven shelf.

- The normal tray is an aluminum tray. The asbestos-covered tray is the same aluminum tray covered with asbestos paper about 1/16 in. thick.
Unless otherwise noted, all tests at elevated temperature were made with the normal tray.

$f$ Specimens not randomly selected but taken from at least three sheets.

g A muffle furnace controlled at $325^{\circ} \pm 10^{\circ} \mathrm{C}$ was used for conditioning these specimens.

$\mathrm{h}$ The flexural strengths for the first and second controls differ significantly for this sample. The test results for various conditions were referred to the data for the control tested at nearly the same time; this is indicated by (A) or (B) following the percentage.

i Four specimens.

¡ Two specimens. 
TABLE 3. Secant modulus of elasticity for specimens of glass-fabric laminates tested under various conditions of temperature and heating a

\begin{tabular}{|c|c|c|c|c|c|c|c|c|c|c|c|c|c|c|c|c|}
\hline \multirow{4}{*}{$\begin{array}{l}\text { Temper- } \\
\text { ature of } \\
\text { heating }\end{array}$} & \multirow{4}{*}{ Special conditions } & \multicolumn{15}{|c|}{ Secant modulus of elasticity in flexure } \\
\hline & & \multicolumn{8}{|c|}{ Unsaturated polyester resin laminates } & \multirow{2}{*}{\multicolumn{2}{|c|}{ Arcylic laminate }} & \multirow{2}{*}{\multicolumn{2}{|c|}{$\underset{\mathrm{B}}{\text { Silicone laminate }}$}} & \multirow{2}{*}{\multicolumn{2}{|c|}{$\begin{array}{c}\text { Phenolic laminate } \\
\mathrm{H}\end{array}$}} & \multirow{2}{*}{$\underset{\mathrm{J}}{\text { M elamine laminate }}$} \\
\hline & & \multicolumn{2}{|c|}{ Laminate A } & \multicolumn{2}{|c|}{ Laminate $\mathrm{E}$} & \multicolumn{2}{|c|}{ Laminate F } & \multicolumn{2}{|c|}{ Laminate $\mathrm{G}$} & & & & & & & \\
\hline & & Mean & Range & Mean & Range & Mean & Range & Mean & Range & Mean & Range & Mean & Range & Mean & Range & Range \\
\hline
\end{tabular}

MOdULUS OF ELASTICITY OF CONTROL SPECIMENS AT $25^{\circ} \mathrm{C}$ (AFTER AT LEAST 7 DAYS AT $25^{\circ} \mathrm{C}$ AND $50 \%$ RELATIVE HUMIDITY)

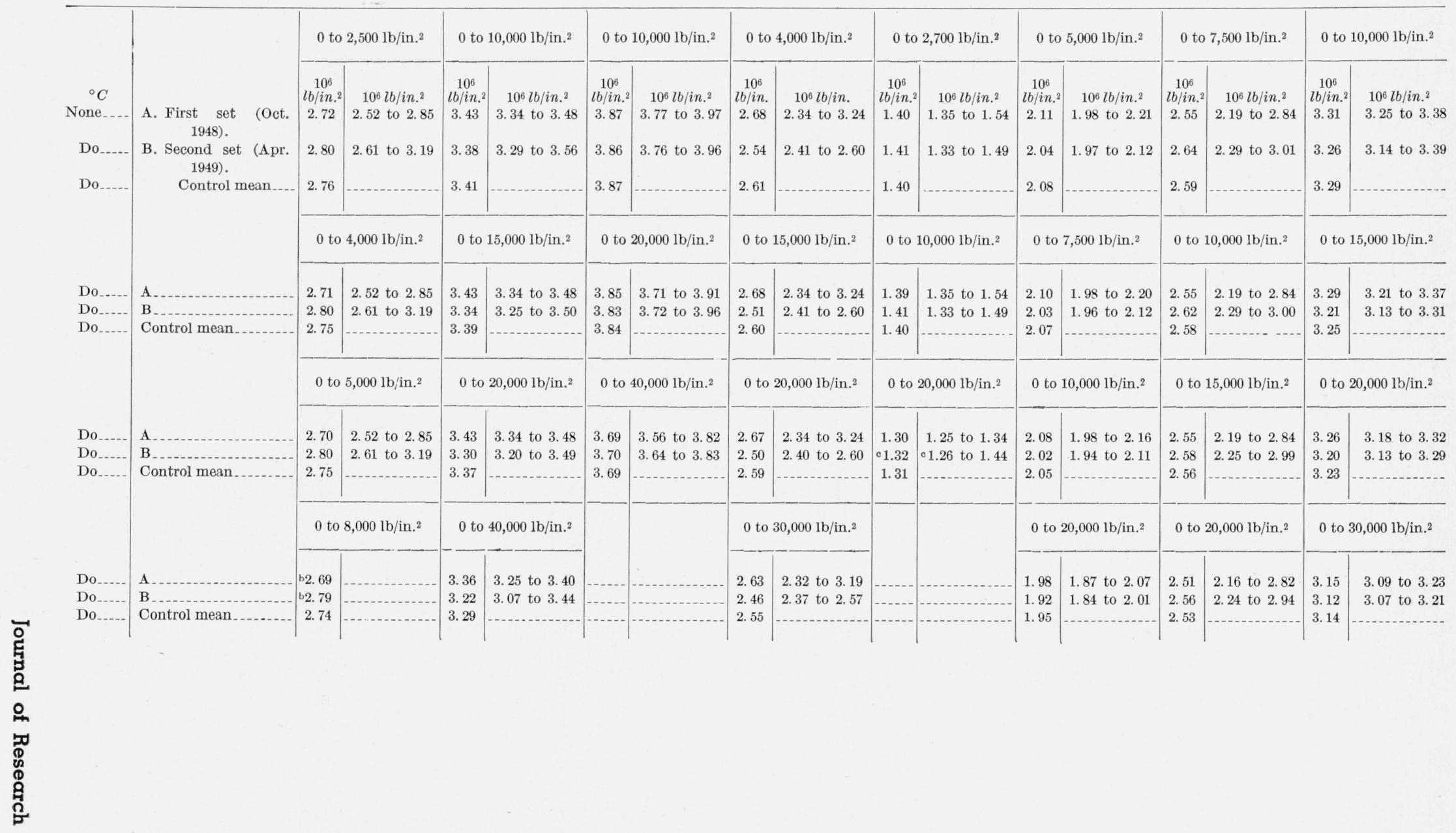




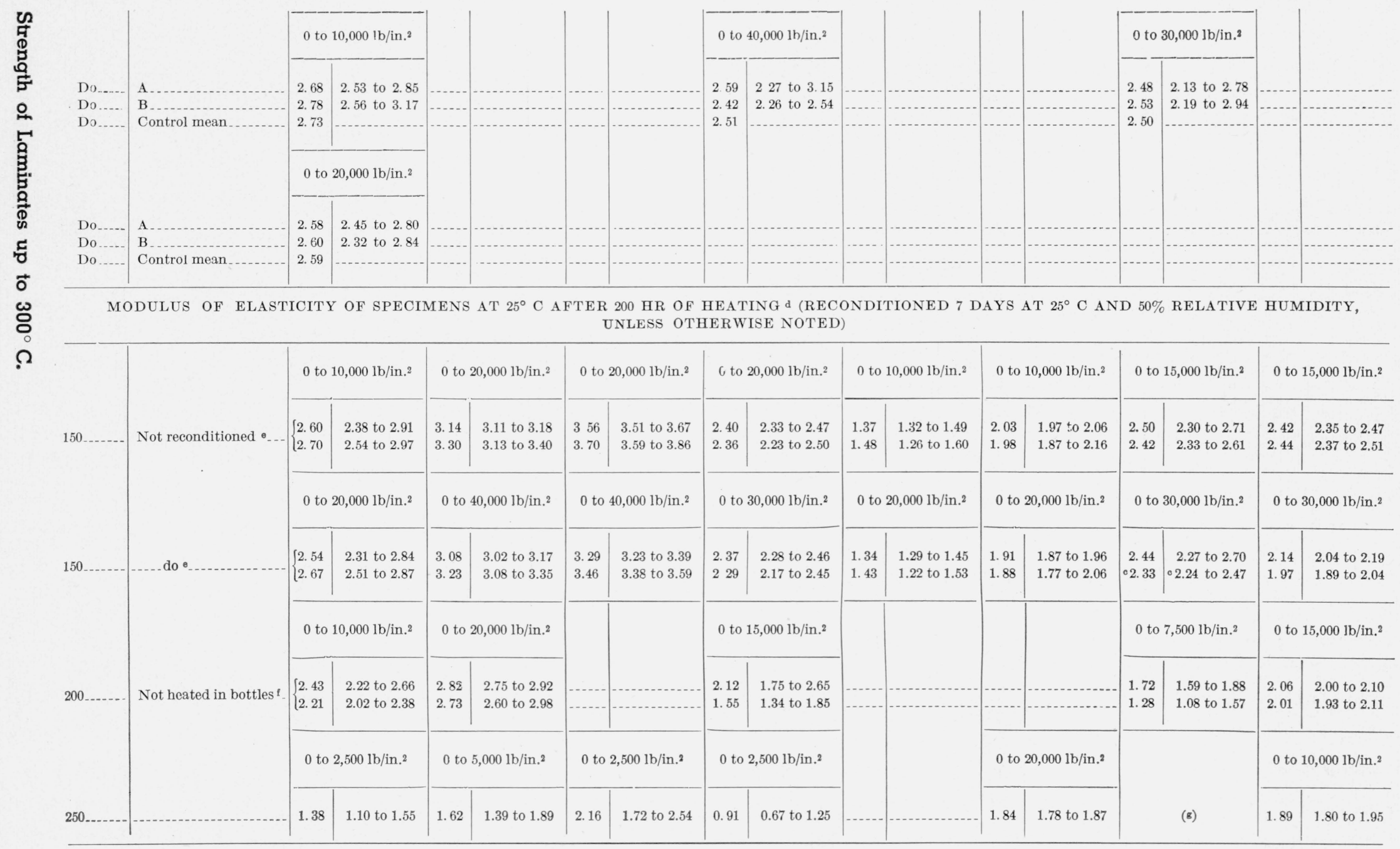

See footnotes at end of table. 
$\mathrm{T}_{\mathrm{ABLE}}$ 3. Secant modulus of elasticity for specimens of glass-fabric laminates tested under various conditions of temperature and heating ${ }^{\mathrm{a}}-\mathrm{Continued.}$

\begin{tabular}{|c|c|c|c|c|c|c|c|c|c|c|c|c|c|c|c|c|c|}
\hline \multirow{4}{*}{$\begin{array}{l}\text { Temper- } \\
\text { ature of } \\
\text { heating }\end{array}$} & \multirow{4}{*}{ Special conditions } & \multicolumn{16}{|c|}{ Secant modulus of elasticity in flexure } \\
\hline & & \multicolumn{8}{|c|}{ Unsaturated polyester resin laminates } & \multirow{2}{*}{\multicolumn{2}{|c|}{$\underset{\mathrm{C}}{\text { Arcylic laminate }}$}} & \multirow{2}{*}{\multicolumn{2}{|c|}{$\underset{\mathbf{B}}{\text { Silicone laminate }}$}} & \multirow{2}{*}{\multicolumn{2}{|c|}{$\begin{array}{c}\text { Phenolic laminate } \\
\mathrm{H}\end{array}$}} & \multirow{2}{*}{\multicolumn{2}{|c|}{$\underset{\mathrm{J}}{\text { Melamine laminate }}$}} \\
\hline & & \multicolumn{2}{|c|}{ Laminate A } & \multicolumn{2}{|c|}{ Laminate $\mathbf{E}$} & \multicolumn{2}{|c|}{ Laminate $\mathrm{F}$} & \multicolumn{2}{|c|}{ Laminate G } & & & & & & & & \\
\hline & & Mean & Range & Mean & Range & Mean & Range & Mean & Range & Mean & Range & Mean & Range & Mean & Range & Mean & Range \\
\hline
\end{tabular}

MODULUS OF ELASTICITY OF SPECIMENS AT A TEMPERATURE $T$ AFTER 0.5 HR AT THE TEMPERATURE $T$

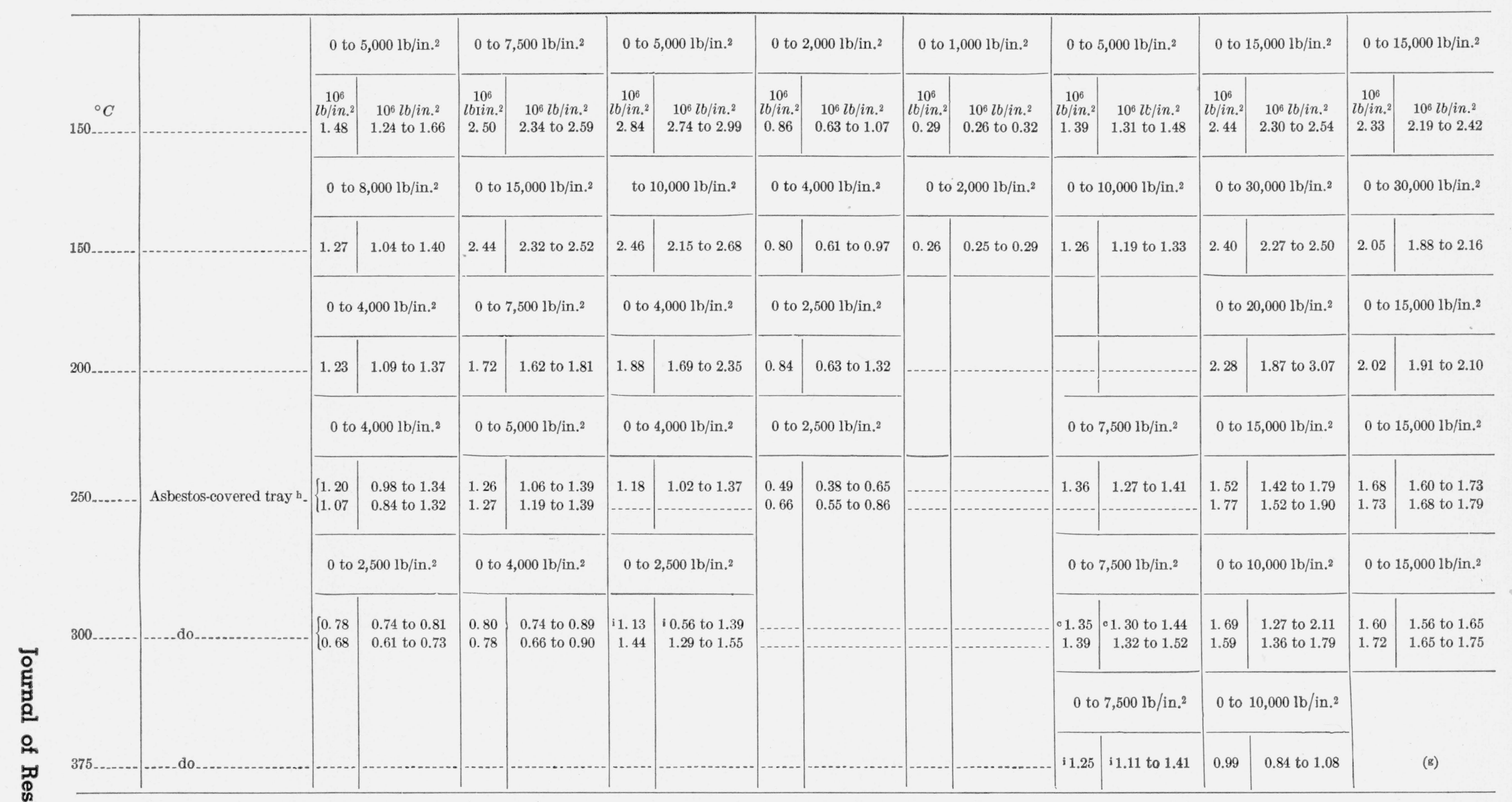


MODULUS OF ELASTICITY OF SPECIMENS AT A TEMPERATURE $T$ AFTER 200 HR AT THE TEMPERATURE $T$ d

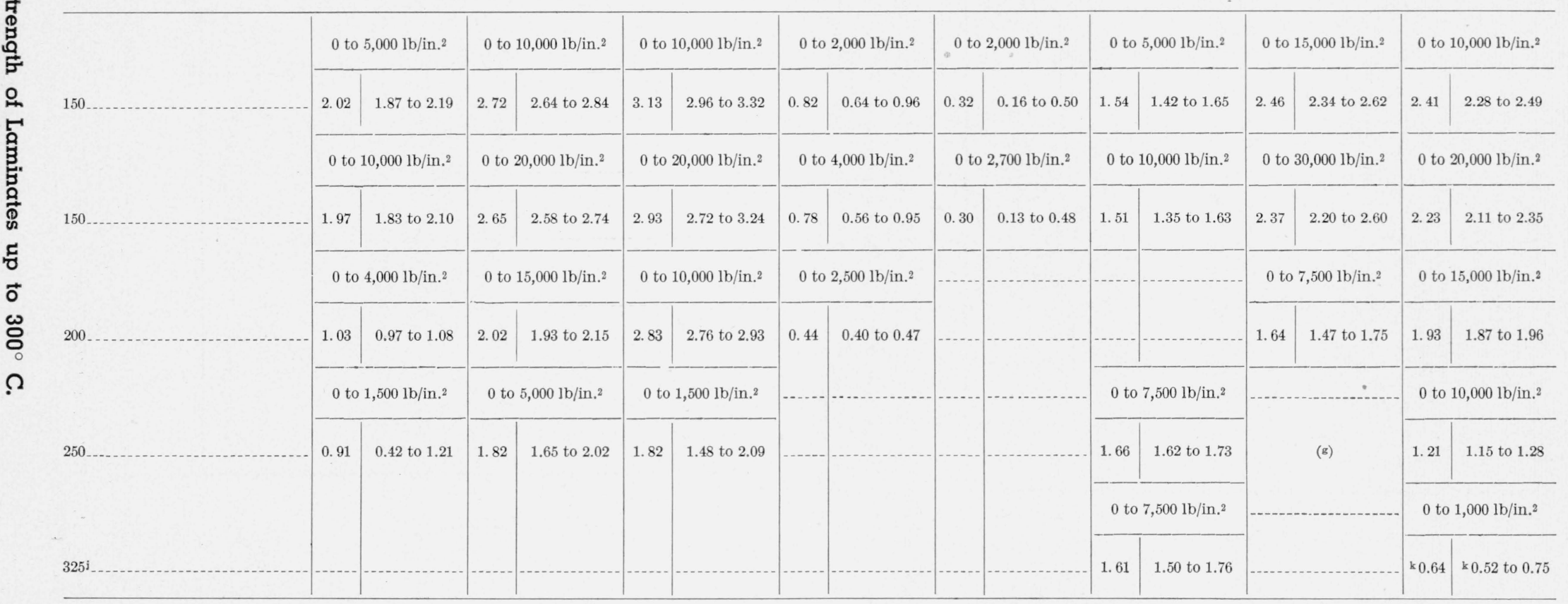

s Specimens approximately $1 / 8 \mathrm{in}$. thick and $1 \mathrm{in}$. wide tested at $0.04 \mathrm{in} . / \mathrm{min}$ relative head motion with a span of $2.0 \mathrm{in}$. Each value is the average for 5 specimens, unless otherwise noted. Specimens taken at random from the sheets, unless otherwise noted. The stress range for the secant modulus $\mathrm{s}$ shown above each set of values.

b Interpolated.

- Four specimens.

d Unless otherwise noted, all specimens that were heated for $200 \mathrm{hr}$ were heated in open wide-

mouthed bottles placed in a circulating-air oven.

- After removal from the oven, specimens kept over calcium chloride for $24 \mathrm{hr}$ prior to testing.

${ }^{t}$ Specimens laid on asbestos board on oven shelf.

g The load-deflection records were too small to permit determination of the modulus.

b The normal tray is an aluminum tray. The asbestos-covered tray is the same aluminum tra

The nith absestral tray (n) temperature were made with the normal tray.

Specimens not randomly selected but taken from at least 3 sheets.

A muffle furnace controlled at $325^{\circ} \pm 10^{\circ} \mathrm{C}$ was used for conditioning these specimens. Two specimens. 


\section{Results and Discussion}

The flexural strength data for the various samples tested under different conditions of temperature and heating are shown in table 2 . Some of the data in table 2 are shown graphically in figures 4 to 6 ; the data that are plotted are for normal conditioning and testing, except when the only tests made were with the tray covered with asbestos. The corresponding data for flexural secant modulus of elasticity are shown in table 3 and figures 7 to 9 . The secant moduli selected for graphing are for a stress range from zero to onehalf to two-thirds of the flexural strength; these secant moduli are expressed as percentages of the values for the controls for the corresponding stress range. The loss-of-weight data for the samples after heating for $200 \mathrm{hr}$ at various temperatures are given in table 4 . The precision of the data and other statistical points are discussed in the next section of this report.

In the detailed discussion of the results that follows, it must be noted that, except for the polyester laminates, only one sample of a given type laminate was tested. Hence only tentative

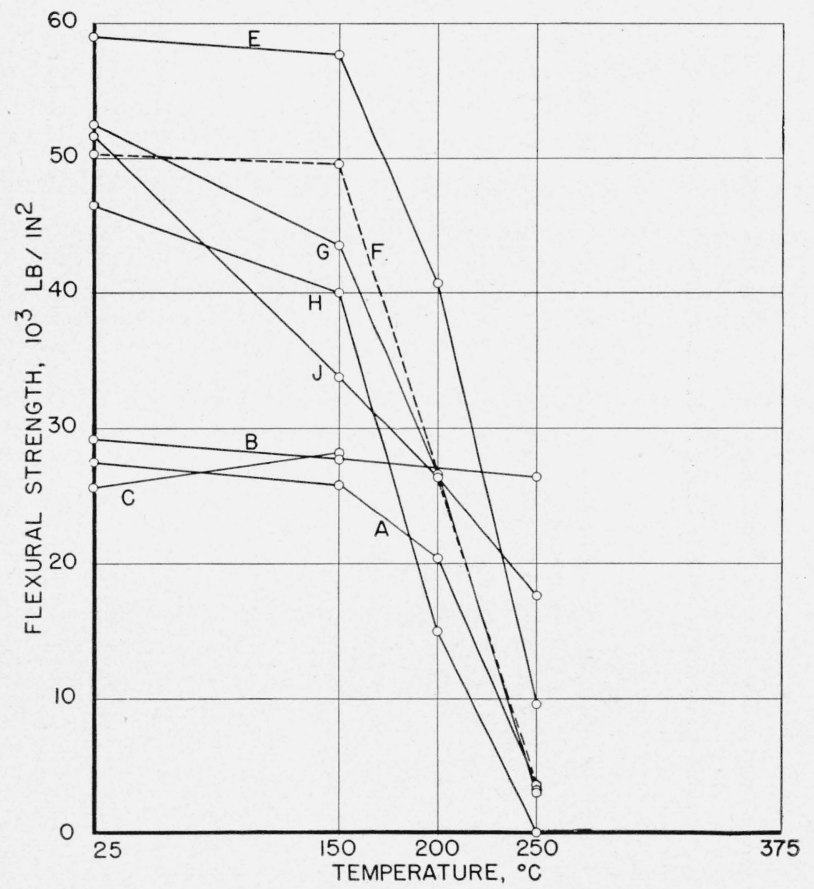

Figure 4. Flexural strength of the laminates at $25^{\circ} \mathrm{C}$ after 200 hours of heating at various temperatures.

$A, E, F, G$, Unsaturated polyester; $B$, silicone; $C$, acrylic addition; $H$, phenolic; $J$, melamine.

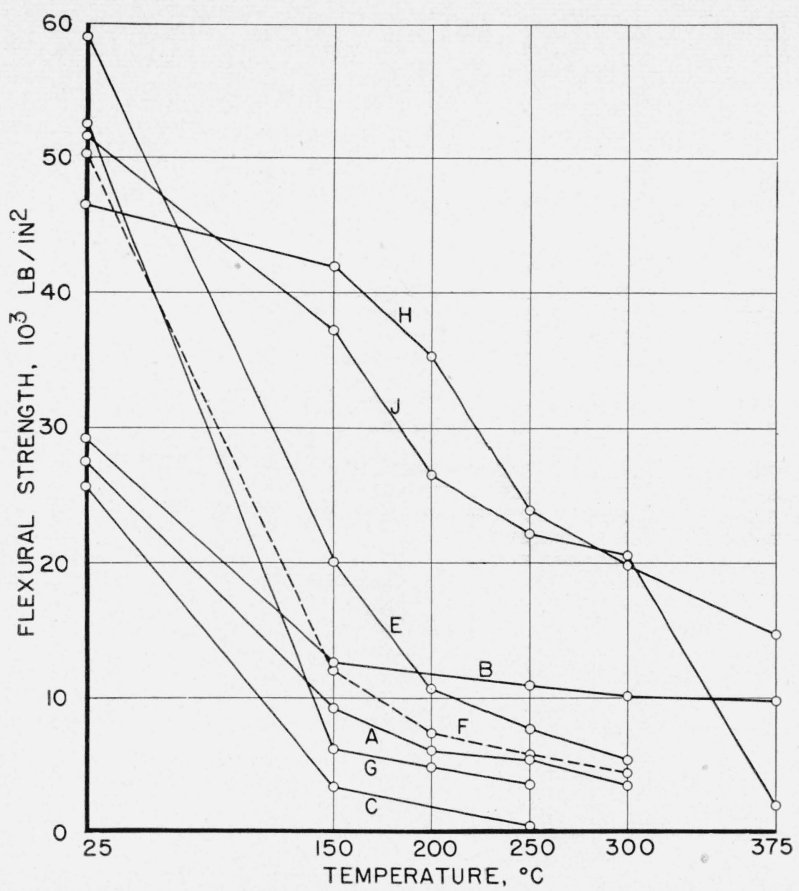

Figure 5. Flexural strength of glass-fabric laminates at a temperature $T$ after 0.5 hour of heating at $T$.

$A, E, F, G$, Unsaturated polyester; $B$, silicone; $C$, acrylic addition; $H$, phenolic; $J$, melamine.

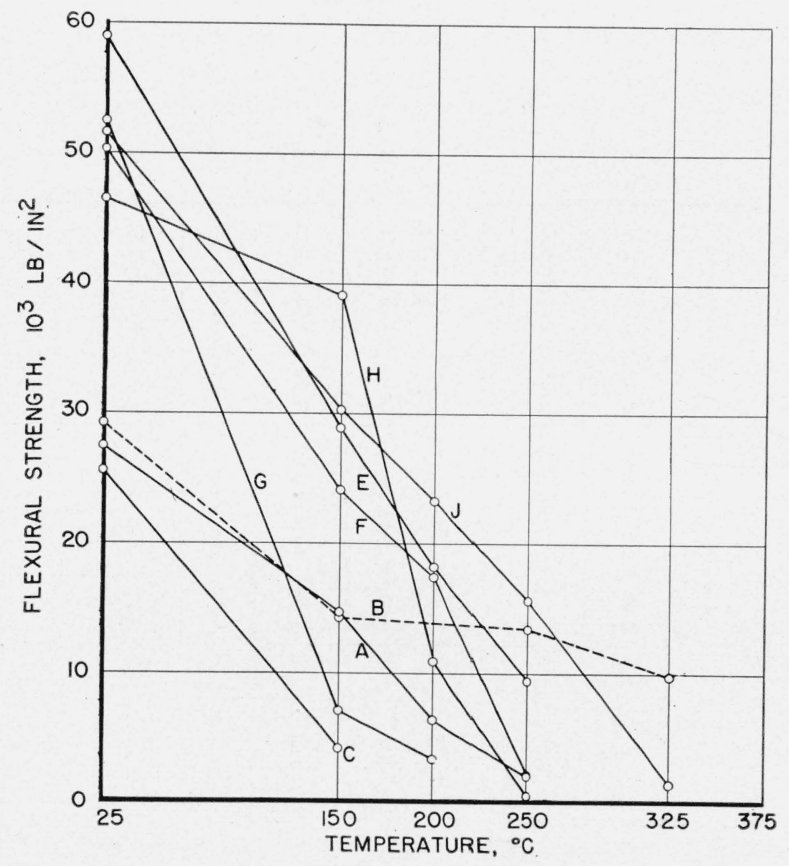

Figure 6. Flexural strength of glass-fabric laminates at a temperature $T$ after 200 hours of heating at $T$.

$A, E, F, G$, Unsaturated polyester; $B$, silicone; $C$, acrylic addition; $H$, phenolic; $J$, melamine. 


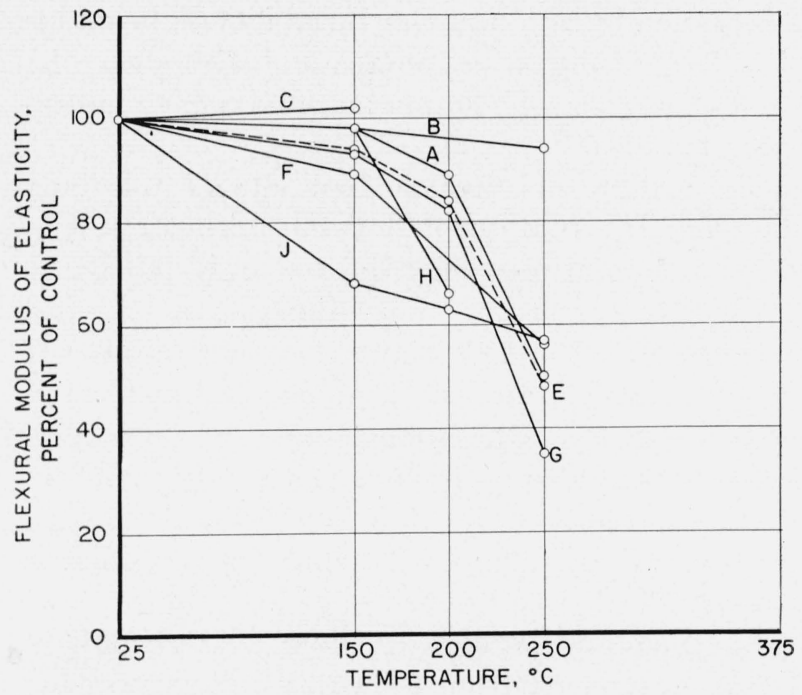

Figure 7. Flexural secant modulus of elasticity of the laminates at $25^{\circ} \mathrm{C}$ after 200 hours at various temperatures.

$A, E, F, G$, Unsaturated polyester; $B$, silicone; $C$, acrylic addition; $H$, phenolic; $J$, melamine.

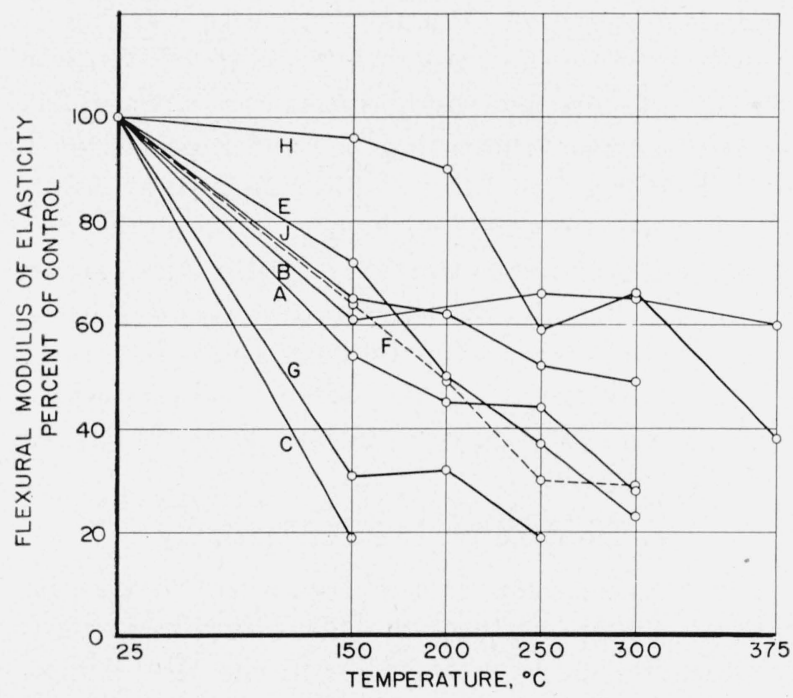

FIgure 8. Flexural secant modulus of elasticity of the laminates at a temperature $T$ after 0.5 hour of heating at $T$.

$A, E, F, G$, Unsaturated polyester; $B$, silicone; $C$, acrylic addition; $H$, phenolic; $J$, melamine.

inferences may be drawn regarding the behavior of the various types of materials.

\section{Flexural Strength}

The four polyester samples (figs. 4 to 6 ) show less than 20-percent loss in strength when tested at $25^{\circ} \mathrm{C}$ after $200 \mathrm{hr}$ of heating at $150^{\circ} \mathrm{C}$. When tested at $25^{\circ} \mathrm{C}$ after $200 \mathrm{hr}$ of heating at tem-

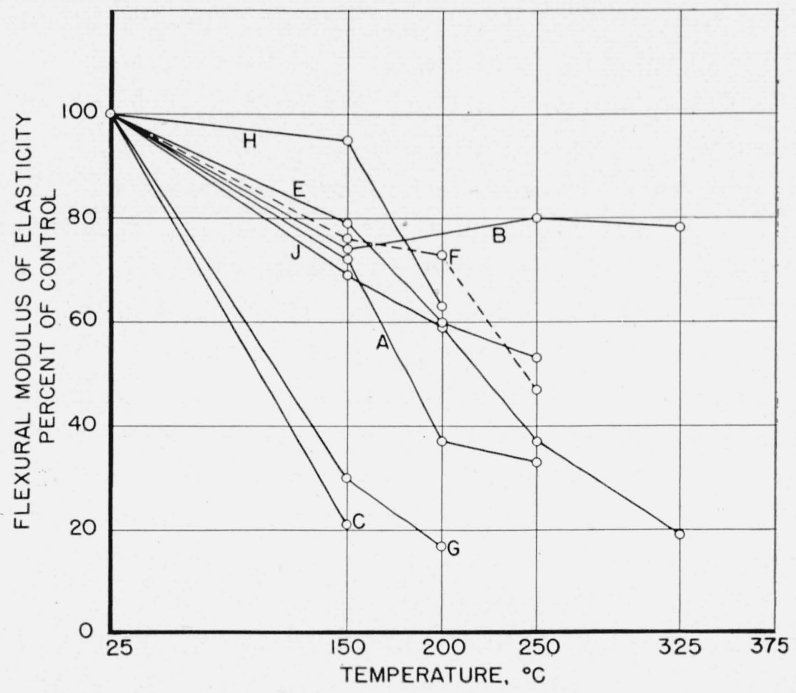

Figure 9. Flexural secant modulus of elasticity of the laminates at a temperature $T$ after 200 hours of heating at $T$.

$A, E, F, G$, Unsaturated polyester; $B$, silicone, $C$, acrylic addition; $H$, phenolic; $J$, melamine.

TABLE 4. Loss of weight and loss of resin by glass-fabric laminates after heating 200 hours at various temperatures ${ }^{\text {a }}$

\begin{tabular}{|c|c|c|c|c|c|c|c|c|}
\hline \multirow{2}{*}{$\begin{array}{r}\text { NBS sample } \\
\text { designation }\end{array}$} & \multicolumn{2}{|c|}{$150^{\circ} \mathrm{C}$} & \multicolumn{2}{|c|}{$200^{\circ} \mathrm{C}$} & \multicolumn{2}{|c|}{$250^{\circ} \mathrm{C}$} & \multicolumn{2}{|c|}{$325^{\circ} \mathrm{C}$} \\
\hline & $\begin{array}{c}\text { Weight } \\
\text { loss }\end{array}$ & $\begin{array}{l}\text { Resin } \\
\text { loss } b\end{array}$ & $\begin{array}{c}\text { Weight } \\
\text { loss }\end{array}$ & $\begin{array}{l}\text { Resin } \\
\text { loss b }\end{array}$ & $\begin{array}{c}\text { Weight } \\
\text { loss }\end{array}$ & $\begin{array}{l}\text { Resin } \\
\text { loss b }\end{array}$ & $\begin{array}{c}\text { Weight } \\
\text { loss }\end{array}$ & $\begin{array}{l}\text { Resin } \\
\text { loss b }\end{array}$ \\
\hline $\begin{array}{l}\text { Unsaturated- } \\
\text { polyester }\end{array}$ & & & & & & & & \\
\hline $\begin{array}{l}\text { resin: } \\
\text { A }\end{array}$ & $\begin{array}{l}\% \\
2.1\end{array}$ & $\begin{array}{r}\% \\
6.0\end{array}$ & $\begin{array}{l}\% \\
7.7\end{array}$ & $\begin{array}{c}\% \\
22.0\end{array}$ & $\begin{array}{c}\% \\
26.2\end{array}$ & $\begin{array}{c}\% \\
74.8\end{array}$ & $\%$ & $\%$ \\
\hline$E \ldots$ & 0.9 & 2.8 & 4.8 & 15.0 & 25.3 & 79.1 & & \\
\hline$F_{\ldots}$ & 1. 2 & 5.0 & 4. 6 & 19. 2 & 18.1 & 75.4 & & \\
\hline$G$ & 2.1 & 5.0 & 10.4 & 24.8 & 31.3 & 74.5 & & \\
\hline $\begin{array}{c}\text { Acrylic addi- } \\
\text { tion resin: } \\
C\end{array}$ & 1.3 & 2.1 & & & & & & \\
\hline Silicone resin: & 0.13 & 0.33 & & & 0.51 & 1.3 & 2. 1 & 5.4 \\
\hline Phenolic resin: & 2. 1 & 4.8 & 8.9 & 20.2 & 34.7 & 79.0 & & \\
\hline $\begin{array}{l}\text { Melamine res- } \\
\text { in: } \\
J\end{array}$ & 3.5 & 7.6 & 4. 9 & 10.7 & 8.4 & 18.3 & & \\
\hline
\end{tabular}

\& The initial weights were determined after at least 7 days' conditioning at $25^{\circ} \mathrm{C}$ and $50 \%$ relative humidity; the final weights were obtained after the specimens had been reconditioned 7 days at $25^{\circ} \mathrm{C}$ and $50 \%$ relative humidity following the $200 \mathrm{hr}$ of heating. Each value is the average for 5 specimens. b Calculated on basis of NBS values for resin content except for laminate $B$; the assumption is made that total weight loss is resin.

peratures above $150^{\circ} \mathrm{C}$, the loss in strength increases rapidly, reaching about 90 percent at $250^{\circ} \mathrm{C}$. These four polyester samples show losses in strength ranging from 50 to 90 percent when tested at $150^{\circ} \mathrm{C}$ after either 0.5 or $200 \mathrm{hr}$ of 
heating at $150^{\circ} \mathrm{C}$. For similar treatment at $250^{\circ} \mathrm{C}$ the loss in strength is at least 80 percent, even for samples tested after only $0.5 \mathrm{hr}$ of heating.

The acrylic laminate $C$, when tested at $150^{\circ} \mathrm{C}$ after either 0.5 or $200 \mathrm{hr}$ of heating, retained only about 15 percent of its initial strength.

The flexural strength at $25^{\circ} \mathrm{C}$ of silicone laminate $B$ was reduced only 10 percent after heating $200 \mathrm{hr}$ at $250^{\circ} \mathrm{C}$; this was the least change observed for any sample for this test condition. In tests at elevated temperatures, after heating the samples for either 0.5 or $200 \mathrm{hr}$, the flexural strength dropped considerably between $25^{\circ}$ and $150^{\circ} \mathrm{C}$. The flexural strength at $150^{\circ} \mathrm{C}$ was about $13,000 \mathrm{lb} / \mathrm{in}^{2}$ compared to a value of $29,000 \mathrm{lb} / \mathrm{in}^{2}$ for the controls. Above $150^{\circ} \mathrm{C}$ the strength diminished very slowly with increase in temperature up to $250^{\circ} \mathrm{C}$ for the $200-\mathrm{hr}$ and up to $375^{\circ} \mathrm{C}$ for the 0.5 -hr heating period, respectively. It is of interest to compare the results obtained in this laboratory with data obtained by the New York Naval Shipyard [9] on two samples of 0.5-in. thick glass-fabric silicone laminate from two sources. Some of these results, as well as data for sample $B$, are shown in table 5 .

TABle 5. Comparison of results for sample B with other flexural data on silicone laminates

\begin{tabular}{|c|c|c|c|c|c|c|}
\hline \multirow{3}{*}{$\begin{array}{l}\text { Temper- } \\
\text { ature of } \\
\text { condition- } \\
\text { ing and test }\end{array}$} & \multicolumn{6}{|c|}{ Flexural strength at $T$ after heating at $T$} \\
\hline & \multicolumn{2}{|c|}{ Sample $I[9]$} & \multicolumn{2}{|c|}{ Sample $I I[9]$} & \multicolumn{2}{|c|}{ Sample $B$} \\
\hline & $\begin{array}{c}\text { Heated } \\
1 \mathrm{hr}\end{array}$ & $\begin{array}{c}\text { Heated } \\
192 \mathrm{hr}\end{array}$ & $\begin{array}{c}\text { Heated } \\
1 \mathrm{hr}\end{array}$ & $\begin{array}{c}\text { Heated } \\
192 \mathrm{hr}\end{array}$ & $\begin{array}{c}\text { Heated } \\
0.5 \mathrm{hr}\end{array}$ & $\begin{array}{l}\text { Heated } \\
200 \mathrm{hr}\end{array}$ \\
\hline $\begin{array}{c}{ }^{\circ} C \\
150 \ldots \\
250 \ldots \ldots\end{array}$ & $\begin{array}{c}10^{3} \mathrm{lb} / \text { in }^{2} \\
7.2 \\
3.6\end{array}$ & $\begin{array}{c}10^{3} \mathrm{lb} / \text { in } .^{2} \\
17.8 \\
12.8\end{array}$ & \begin{tabular}{|}
$10^{3} \mathrm{lb} / \mathrm{in}^{2}{ }^{2}$ \\
9.8 \\
5.0
\end{tabular} & \begin{tabular}{|}
$10^{3} \mathrm{lb} / \mathrm{in}^{2}{ }^{2}$ \\
12.0 \\
4.2
\end{tabular} & $\begin{array}{c}10^{3} \mathrm{lb} / \text { in }^{2} \\
12.6 \\
10.9\end{array}$ & $\begin{array}{r}10^{3} l b / \text { in. }^{2} \\
14.3 \\
13.4\end{array}$ \\
\hline $\begin{array}{c}\text { Control val- } \\
\text { ues. }\end{array}$ & 29 & 9.9 & 20 & 0.0 & & 9.2 \\
\hline
\end{tabular}

Sample $I$ was reported to be softened at $250^{\circ} \mathrm{C}$ when heated only a short time at that temperature; in view of the improvement on further heating, this behavior was believed to be caused by further cure [9]. To test this idea they report [9] that specimens of sample $I$ were heated for $72 \mathrm{hr}$ at $250^{\circ} \mathrm{C}$, reconditioned for $72 \mathrm{hr}$ at $25^{\circ} \mathrm{C}$ and 50 -percent relative humidity, and then tested at $250^{\circ} \mathrm{C}$ after 1 to $4 \mathrm{hr}$ at $250^{\circ} \mathrm{C}$; flexural strengths of $11,000 \mathrm{lb} / \mathrm{in}^{2}$ were obtained. These results give some indication of the variability in behavior of different silicone laminates and also show the possibility with such laminates of having an undercured material.

The sample of phenolic laminate $H$ was outstanding in retention of flexural strength at elevated temperatures when heated only $0.5 \mathrm{hr}$ at the test temperature. For example, the flexural strength at $375^{\circ} \mathrm{C}$ for this test condition was $15,000 \mathrm{lb} /$ in. $^{2}$ compared to $46,000 \mathrm{lb} / \mathrm{in}^{2}$ for the control (fig. 5). The same sample, however, was seriously degraded by prolonged heating at $250^{\circ} \mathrm{C}$; after such treatment it exhibited a flexural strength much less than $1,000 \mathrm{lb} /$ in. $^{2}$ when tested either at $250^{\circ}$ or $25^{\circ} \mathrm{C}$.

The melamine laminate $J$ shows a nearly steady decline in strength from $25^{\circ}$ to $250^{\circ} \mathrm{C}$ or more for the three heating and testing conditions. The flexural strength is reduced to about two-thirds, one-half, and one-third for heating at $150^{\circ}, 200^{\circ}$, and $250^{\circ} \mathrm{C}$, respectively. At a given temperature $T$, the strength at $T$ after $0.5 \mathrm{hr}$ of heating is slightly greater than that for tests at $25^{\circ} \mathrm{C}$ after $200 \mathrm{hr}$ of heating, and the latter strength is slightly greater than that at a temperature $T$ after $200 \mathrm{hr}$ of heating. These flexural strength values were compared with data obtained by the New York Naval Shipyard [9]. The latter laboratory made tests similar to those described in this report on a 0.5 -in.-thick melamine laminate. The general trend of the strength-temperature data given in [9] is similar to that shown in figures 4 to 6 for sample $J$.

\section{Flexural Modulus of Elasticity}

For a given sample the trend shown by the flexural secant modulus of elasticity versus temperature graph is quite similar to the plot of flexural strength versus temperature for the same condition of heating and testing. However, for each laminate the percentage loss in flexural modulus of elasticity for a given test condition is always less than the loss in flexural strength for that test condition. ${ }^{3}$

\section{Correlation Between Changes in Flexural Strength and Modulus of Elasticity}

In figure 10 the flexural strength in percentage of control is plotted against the flexural modulus of elasticity in percentage of control for all the lami-

\footnotetext{
3 There were exceptions to this statement when the loss in the flexural property was $5 \%$ or iess. Such losses are not considered significant.
} 
nates except $C$. Data for all conditions in tables 2 and 3 were used, except that the values for "Special conditions" were not plotted unless no other data at a given temperature were available. The modulus of elasticity data for the lowest stress range was used in the case of tests at $150^{\circ} \mathrm{C}$. It is evident that a correlation exists between these two quantities; furthermore, it appears that the correlation equation is probably different for the polyester laminates as compared to the melamine laminate $J$. A detailed analysis of the correlation was not made, as only in the case of the polyester laminates was there more than one sample of a given type of laminate.

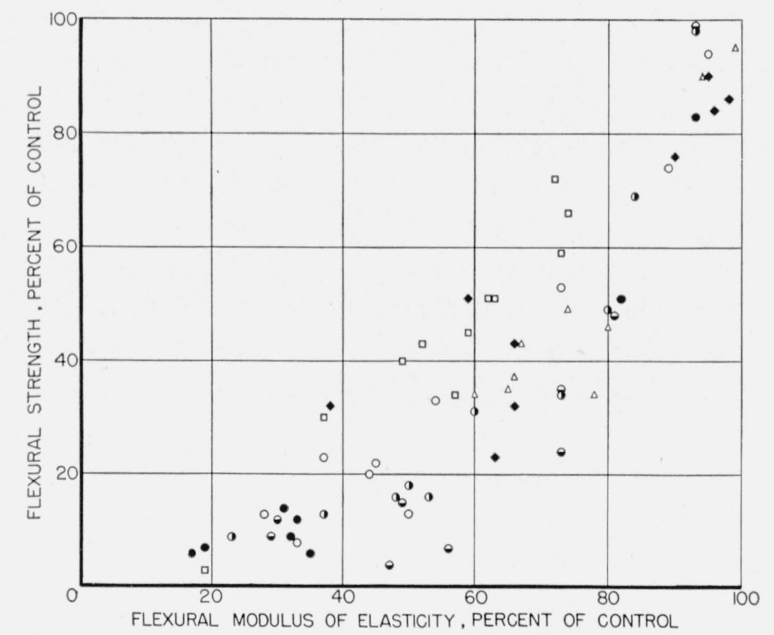

Figure 10. Correlation between flexural strength and flexural secant modulus of elasticity.

Data taken from tables 2 and 3. Sample A, O; E, O; F, ๑; G, •; B, $\triangle$; J, $\square ;$ H, $\bullet$.

\section{Relative Heat Resistance of the Laminates}

To give a concise comparison of the laminates as regards their retention of flexural properties at elevated temperatures, a table was prepared in the following manner: For each sample the temperatures in figures 4 to 6 were noted for which the flexural strength was 30 percent or more of the flexural strength for the control for all three conditions of heating and testing. The same procedure was followed for the corresponding secant modulus of elasticity values, except that the percentage was 50 instead of 30 . These temperature limits are shown in table 6 . Since it was often necessary to interpolate the stress range as well as the modulus of elasticity, the temperatures given in table 6 for the modulus data are less accurate
TABLE 6. Relative heat resistance of glass-fabric laminates, based on flexural properties

\begin{tabular}{|c|c|c|c|}
\hline \multirow[t]{2}{*}{$\begin{array}{l}\text { NBS sample } \\
\text { designation }\end{array}$} & \multirow{2}{*}{$\begin{array}{l}\text { Temperature } T \text { at } \\
\text { which flexural } \\
\text { strength is at least } \\
30 \% \text { of control } \\
\text { value for the three } \\
\text { types of tests }\end{array}$} & \multicolumn{2}{|c|}{$\begin{array}{l}\text { Temperature } T \text { at which flexural } \\
\text { secant modulus of elasticity is } \\
\text { at least } 50 \% \text { of control value for } \\
\text { the three types of test }\end{array}$} \\
\hline & & Temperature & Stress range \\
\hline $\begin{array}{l}\text { Uns a turated } \\
\text { polyester resin: }\end{array}$ & ${ }^{\circ} \mathrm{C}$ & ${ }^{\circ} \mathrm{C}$ & Tbliz ${ }_{2}^{2}$ \\
\hline A & 150 & $150 \ldots$ & 0 to 6,000 . \\
\hline$E_{\ldots} \ldots$ & 150 & 200 & 0 to 7,500 . \\
\hline$F_{\ldots} \ldots$ & 140 (estimated) & 200 & 0 to 4,000 . \\
\hline G & 130 (estimated)....... & Less than $150 \ldots$ & 0 to 4,000 . \\
\hline $\begin{array}{l}\text { Acrylic addition } \\
\text { resin: } \\
\quad \mathrm{C}\end{array}$ & Much less than 150 & Much less than 150 & 0 to 5,000 . \\
\hline Silicone resin: & & & \\
\hline B & 325 & $\begin{array}{l}325 \text { (for } 65 \% \text {, esti- } \\
\text { mated). }\end{array}$ & 0 to 7,500 \\
\hline $\begin{array}{l}\text { Phenolic resin: } \\
\text { H }\end{array}$ & $200 \ldots$ & 220 (estimated) & 0 to 5,000 . \\
\hline Melamine resin: & $250_{-}$ & 220 (estimated) & 0 to 10,000 . \\
\hline
\end{tabular}

a Tests at $25^{\circ} \mathrm{C}$ after $200 \mathrm{hr}$ of heating at temperature $T$, and tests at temperature $T$ after 0.5 or $200 \mathrm{hr}$ of conditioning at temperature $T$.

than the temperatures for the flexural strength. It must be emphasized in addition, that for the modulus of elasticity data, temperatures different from those given in table 6 would apply for other stress ranges; when the stress-strain diagram is nearly linear for the ranges considered, the effect of differing stress range is slight.

It is of interest to compare the values in table 6 with data obtained by Sieffert and Schoenborn [10]. The latter authors determined the weight loss as a function of time for a number of laminates at various temperatures; from these data curves were plotted of weight loss versus temperature. It was found that for each material the weight loss as a function of temperature began to increase rapidly beyond a certain temperature. By using an arbitrary criterion, a "critical thermal instability temperature" was determined from the plotted data. The values Sieffert and Schoenborn reported for several laminates are shown in table 7 .

It is evident that there is close agreement between the critical thermal instability temperature and the temperatures given in table 5 for retention of 30 percent of original flexural strength.

\section{Effect of_Speed of Heated Air on Changes in Flexural Properties}

The data in tables 2 and 3 for tests at $25^{\circ} \mathrm{C}$ after heating the specimens at $200^{\circ} \mathrm{C}$ either on the oven shelf or in open bottles were examined 
TABLE 7. Critical thermal instability temperature and resin loss data reported by Sieffert and Schoenborn [10] for glassfabric laminates

\begin{tabular}{|c|c|c|c|}
\hline Glass-fabric laminate & $\begin{array}{l}\text { Resin } \\
\text { con- } \\
\text { tent }\end{array}$ & $\begin{array}{c}\text { Critical } \\
\text { thermal } \\
\text { instabil- } \\
\text { ity tem- } \\
\text { perature } \\
\left(\begin{array}{c}M=4,72-\mathrm{hr} \\
\text { data })\end{array}\right.\end{array}$ & $\begin{array}{l}\text { Temper- } \\
\text { ature for } \\
5 \% \text { resin } \\
\text { loss (72 } \\
\text { hr) }\end{array}$ \\
\hline Polyester.... & $\begin{array}{c}\text { Percent } \\
31\end{array}$ & ${ }^{\circ} C$ & ${ }^{\circ} C$ \\
\hline Silicone $A$ & 52 & 350 & 375 \\
\hline Silicone $B$ & 40 & 355 & 250 \\
\hline Low-pressure phenolic... & 28 & 210 & 220 \\
\hline $\begin{array}{l}\text { Melamine-formaldehyde } \\
\text { A }\end{array}$ & 40 & 235 & 115 \\
\hline $\begin{array}{l}\text { Melamine-formaldehyde } \\
\text { B }\end{array}$ & 45 & 240 & 100 \\
\hline
\end{tabular}

statistically (see section V). It was found that both the flexural strengths and flexural moduli of elasticity for the polyester laminates and the phenolic laminate were significantly lower for the case of heating on the oven shelf, i. e., in rapidly moving air, as compared to heating in the open bottles. However, for the melamine laminate $J$ the differences were not significant.

These results indicate that information on the effect of prolonged heating on the glass-fabric laminates under different atmospheric conditions is needed. The degradation of the resin may depend on the rate of removal of degradation products as well as the rate at which heated air containing oxygen, an important agent for some degradation reactions, is swept over the surface of the material. It follows that the use of data of the type presented in this report on the properties of laminates after prolonged heating should be used for design purposes with caution, since in practice the conditions of heating may differ widely from those that apply to the data given here. Likewise, interlaboratory comparisons of a given laminate may give discordant results if the heating conditions are not duplicated.

\section{Loss of Weight on Heating}

After $200 \mathrm{hr}$ of heating at only $150^{\circ} \mathrm{C}$, all the samples except the silicone exhibited losses in resin of 2 to 8 percent of the initial amount, with the melamine laminate showing the greatest loss. As the temperature of heating was raised, the loss in amount of resin increased very rapidly for all the polyester laminates and the one phenolic laminate. For these samples the resin loss is roughly fourfold at $200^{\circ} \mathrm{C}$ and twelve- to thirty-fold at $250^{\circ} \mathrm{C}$, compared to the losses at $150^{\circ} \mathrm{C}$. In contrast to this behavior the melamine laminate showed much less rapid increases in resin loss (see table 4).

\section{Statistical Analysis}

\section{Precision of Results}

The standard deviation was determined for the data in tables 2 and 3 for tests at various conditions. For a given sample it was observed that the standard deviation tended to be proportional to the mean value. For this reason, further analysis was made with the coefficient of variation instead of the standard deviation. The coefficient of variation is defined as 100 times the ratio of the standard deviation to the mean value.

The coefficient of variation was not reported for each flexural strength value in table 2 or each modulus of elasticity value in table 3 because such statistics, based on only five observations, are subject to wide variability. It was decided to analyze the individual coefficient of variation with respect to its variation from sample to sample and between the different temperatures. This was done to determine in what manner these data could best be combined for more reliable estimates of precision. The analyses are discussed in the following paragraphs.

\section{(a) Flexural Strength}

The coefficient of variation $\left(C_{v}\right)$ was determined for all the values in table 2. A statistical analysis of some of these data indicates some variation of the value of $C_{0}$ between samples. No consistent trend for the effect of conditioning or test temperature on the value of $C_{v}$ for the samples was noted. Therefore, the estimates of $C_{v}$ within each sample were pooled with the following results: 


\begin{tabular}{|c|c|}
\hline Laminate & $C_{v}$ \\
\hline $\begin{array}{l}\text { Unsaturated polyester: } \\
A_{A} \\
E_{1} \\
G_{-} \\
\text {Acrylic addition: } \\
\quad C_{\text {Silicone: }} \\
\quad B_{-} \\
\text {Phenolic: } \\
\quad H_{-} \\
\text {Melamine: } \\
\quad J_{-}\end{array}$ & $\begin{array}{l}\text { Percent } \\
\text { 6. } 6 \\
5.1 \\
7.3 \\
8.4 \\
\text { 8. } 8 \\
\text { 5. } 2 \\
10 \\
2.9\end{array}$ \\
\hline
\end{tabular}

In a few instances, usually for the highest testing or conditioning temperature and when the flexural strength was a small fraction of the initial value, a very large value of $C_{v}$ was obtained; such values were omitted in obtaining the above estimates of $C_{v}$.

(b) Flexural Modulus of Elasticity

The coefficient of variation was determined for the modulus values in table 3 . A statistical analysis was carried out for the tests made either at $25^{\circ} \mathrm{C}$ or at a temperature $T$ after $200 \mathrm{hr}$ of heating at $T$. It was found that (1) the effect of conditioning temperature on $C_{v}$ varies significantly from sample to sample; (2) $C_{v}$ cannot be assumed to be the same for all samples; and (3) the effect of testing temperature, i. e., $25^{\circ} \mathrm{C}$ compared to $T$, on $C_{v}$ varies significantly from sample to sample. The above effects do not seem to be important except the sample-to-sample variability. It was therefore decided to combine the estimates of $C_{v}$ for the various samples. The estimated values of $C_{v}$ for the modulus of elasticity are:

\begin{tabular}{|c|c|}
\hline Laminate & $C_{\vartheta}$ \\
\hline 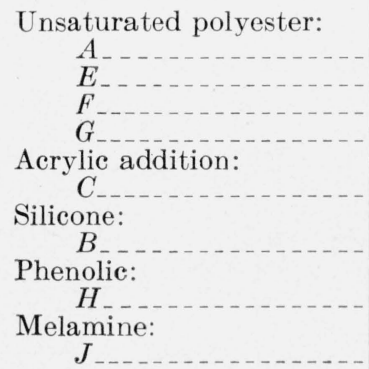 & $\begin{array}{l}\text { Percent } \\
7.5 \\
5.1 \\
8.8 \\
14 \\
7 \\
\quad 4.5 \\
10 \\
\quad \\
3.0\end{array}$ \\
\hline
\end{tabular}

In a few instances, usually for the highest testing or conditioning temperature and when the modulus of elasticity was a small fraction of the initial value, a very large value of $C_{v}$ was obtained; such values were omitted in obtaining the above estimates of $C_{v}$.

\section{Thermal Shock in Tests After 0.5 Hour of Heating}

A statistical analysis was made of the flexural data for the tests after $0.5 \mathrm{hr}$ of heating in which duplicate sets of specimens were tested, one set with and one set without asbestos paper on the metal specimen tray. All the samples do not behave alike with respect to differences in flexural strength or modulus of elasticity for the two tray conditions. Although in some cases there appears to be a significant effect, the data as a whole do not support the assumption that the thermal shock is serious.

\section{Effect of Heating in Still Air Compared to Heating in Rapidly Moving Air}

A statistical analysis was made of the flexural data for the tests at $25^{\circ} \mathrm{C}$ after $200 \mathrm{hr}$ of heating at $200^{\circ} \mathrm{C}$ with the specimens exposed (1) in open bottles, and (2) on the oven shelf. It was found that flexural strength and flexural modulus of elasticity were similarly affected for specimens contained in open bottles compared to those placed directly on the oven shelf during the heating period. The data for each sample were tested separately. Samples $A, G$, and $H$ all show significantly greater losses in flexural strength and modulus of elasticity for shelf heating compared to bottle heating. For sample $E$ the effect was significant for flexural strength but not for modulus of elasticity. For sample $J$ no significant effect was noted.

\section{Conclusions}

The silicone laminate is superior to the other laminates tested in retention of flexural properties at temperatures of $250^{\circ}$ to $300^{\circ} \mathrm{C}$. When tested at about $325^{\circ} \mathrm{C}$ after either 0.5 or $200 \mathrm{hr}$ of heating at that temperature, this laminate retained at least 30 percent of its initial flexural strength and over 50 percent of its initial flexural modulus of elasticity. 
The phenolic laminate showed good retention of its flexural properties when tested at elevated temperatures after heating for $0.5 \mathrm{hr}$ at the test temperature. When tested in this way at $375^{\circ}$ $\mathrm{C}$, the flexural strength was $15,000 \mathrm{lb} / \mathrm{in}^{2}$, and the modulus of elasticity was $1.0 \times 10^{6} \mathrm{lb} / \mathrm{in}^{2}$, values roughly one-third of the corresponding values for the controls. The behavior of the phenolic laminate after prolonged heating was much less satisfactory; at $25^{\circ}$ or $250^{\circ} \mathrm{C}$ after $200 \mathrm{hr}$ of heating at $250^{\circ} \mathrm{C}$ the flexural strength was much less than $1,000 \mathrm{lb} / \mathrm{in}^{2}$.

The melamine laminate, although much inferior to the phenolic laminate when tested at a temperature of $375^{\circ} \mathrm{C}$ after $0.5 \mathrm{hr}$ of heating, was superior to the phenolic in retention of flexural strength after $200 \mathrm{hr}$ of heating at $250^{\circ} \mathrm{C}$.

The four polyester laminates lost at least 80 percent of their flexural strengths when tested at $250^{\circ} \mathrm{C}$ after either 0.5 or $200 \mathrm{hr}$ of heating.

The arcylic addition laminate lost at least 80 percent of its flexural strength when tested at $150^{\circ} \mathrm{C}$ after either 0.5 or $200 \mathrm{hr}$ of heating.

For each laminate and each test condition, loss in flexural modulus of elasticity correlates with loss in flexural strength; the former loss is less than the latter.

The loss in flexural properties during prolonged heating may depend on the method of exposing the specimens in the oven. For specimens of the polyester and phenolic laminates, heating in a circulating-air oven in open bottles caused significantly less loss in flexural properties than did heating on the shelves of the oven.

These conclusions, except for the polyester laminates, are based on data for only one sample of each type of glass-fabric laminate and hence can be considered only tentatively as being representative of the various types of material.

The courtesy of the American Cyanamid Co., Dow Corning Corp., E. I. du Pont de Nemours \& Co., Formica Co., Monsanto Chemical Co., Plaskon Division of the Libbey-Owens-Ford
Glass Co., and the Resinous Products Division of the Rohm \& Haas Co. in furnishing materials for use in this investigation is gratefully acknowledged. The cooperation of the following members of the staff of the National Bureau of Standards also is appreciated: M. N. Geib, who assisted in the design of the apparatus; H. W. Bailey and W. O. Bottamiller, who constructed the apparatus; and J. Mandel, who made the statistical analysis.

\section{References}

[1] P. M. Field, Basic physical properties of laminates, Modern Plastics 20, 91 (Aug. 1943).

[2] H. R. Meyer and E. C. O. Erickson, Factors affecting the strength of papreg. Some strength properties at elevated and subnormal temperatures. Forest Products Laboratory Report No. 1521 (Jan. 1945).

[3] W. C. Renwick, Properties of plastic laminates, Part VI. Naval Air Exp. Sta. Report TED NAM 25217.0 (June 3, 1944).

[4] D. A. Shinn, Impact data for plastic materials at various temperatures, Air Corps Tech. Report No. 5012 (Aug. 9, 1943); Modern Plastics 22, 145 (July 1945).

[5] E. O. Hausmann, A. E. Parkinson, and G. H. Mains, Heat resistance of laminated plastics, Modern Plastics 22, 151 (Nov. 1944).

[6] J. J. Lamb, I. Albrecht, and B. M. Axilrod, Impact strength and flexural properties of laminated plastics at high and low temperatures, NACA Tech. Note No. 1054 (1946).

[7] J. J. Lamb, I. Albrecht, and B. M. Axilrod, Tensile and compressive properties of laminated plastics at high and low temperatures, NACA Tech. Note No. 1550 (1948).

[8] P. Norelli and W. H. Gard, Temperature effect on strength of laminates. Ind. Eng. Chem. 37, 580 (June 1945).

[9] Investigation of the effects of high and low temperature conditioning on properties of laminated thermosetting plastic materials. Report No. 4860A, Special Summary; Material Laboratory, New York Naval Shipyard (Aug. 29, 1949).

[10] L. E. Sieffert and E. M. Schoenborn, Critical thermal instability temperature of laminated plastic electrical insulation. Navy Dept., Bureau of Ships; manuscript submitted to Ind. Eng. Chem. for publication.

Washington, February 23, 1950. 